\title{
LA FORMACIÓN DE UNA BURGUESÍA AGRARIA EN EL INTERIOR CASTELLANO. EL EJEMPLO DE LA VILLA DE ALBACETE (1680-1830)*
}

\author{
COSME JESÚS GÓMEZ CARRASCO
}

Facultad de Humanidades de Albacete (UCLM) - EHESS (París)

\section{INTRODUCCIÓN}

El periodo que se aborda en este trabajo estuvo caracterizado a nivel económico por la transición del feudalismo al capitalismo. En la historiografía, y en las ciencias sociales en general, hasta hace dos décadas la visión que de esta época se tenía tendía a marcar sus deficiencias y la ruptura que supuso en esta inercia depresiva los procesos de modernización y de industrialización. Conceptos a veces muy ambiguos, que suelen ir acompañados uno de otro y que quieren escenificar unos momentos de cambio, ruptura y transformación de la realidad social, económica, política y cultural de la sociedad. Wrigley ya enfatizó los problemas de definición de ambos términos, sobre todo en el caso de modernización ${ }^{1}$. A esta palabra se le atribuyen -con asiduidad- un conjunto de cambios y profundas transformaciones en la sociedad. Pero su composición, peso, tamaño y la lista concreta de cambios asociados suele variar. Muy coligado con la idea de modernización suele ir otro concepto como es el de la racionalidad. En comparación con las sociedades tradicionales - preindustriales - la utilidad se maximiza en las sociedades modernas -industriales y postindustriales ${ }^{2}-$. Lo cierto es que hasta hace poco, el crecimiento económico de este periodo clave se había explicado siempre con

\footnotetext{
* Este trabajo forma parte del Proyecto de Investigación «Sociedad, familias y grupos sociales. Redes y estrategias de reproducción socio-cultural en Castilla durante el Antiguo Régimen (siglos XV-XIX)», financiado por el Ministerio de Educación y Ciencia (HUM2006-09559).

1. WRIGLEY, E. A.: «The process of modernization and the Industrial Revolution in England», en Journal of Interdisciplinary History, vol. 3, nº 2, 1972, pág. 228.

2. SPEngleR, J.J.: «Mercantilist and Physiocratic Growth Theory», in HoseliTz: Theories of Economic Growth, 1961, págs. 3-64.
} 
respecto al cambio en la productividad y en los sectores industriales ${ }^{3}$. Sin embargo, en la historia social y económica actual se ha vuelto con gran interés hacia el consumo y la expansión comercial que entre 1750-1850 se vivió en Europa ${ }^{4}$.

Muy complejo es, pues, poder adentrarse correctamente en un mundo económico en transición como es el que vamos a abordar ${ }^{5}$. Más aún desde la perspectiva del comercio, el mercado y los hábitos de consumo. Pero de necesario análisis para comprender la esfera socioeconómica que envolvía al crecimiento y consolidación de la burguesía comercial en una villa del interior castellano como Albacete. Un grupo social que fue poco uniforme -es cierto- y también de bases económicas complejas ${ }^{6}$. Pero que se nutrió del crecimiento que en esos momentos vivió la villa albacetense, y en el que interactuó consolidando una posición de poder del que un siglo atrás carecía ${ }^{7}$. Consecuencia de las transformaciones generales sufridas a lo largo del siglo XVIII en la sociedad y la economía albacetenses (sobre todo en el incremento de la producción y de la población) nació un nuevo sistema comercial que se superpuso y cambió al antiguo $^{8}$. Unos cambios que chocaron con unas estructuras rígidas, heredadas del pasado. Y es que la organización de los mercados internacionales, pero sobre todo interiores, es relativamente muy poco conocida. La causa de la organización de dichos mercados, así como los efectos que se produjeron gracias a la creación de unas redes de distribución, deben ser examinadas para comprender correctamente este trascendental periodo ${ }^{9}$.

La doble vertiente comercial albacetense -redistribuidora de productos en la comarca, y centro de flujos comerciales más amplios, de Levante a Madrid- favoreció el crecimiento de un grupo social difuso. Unas familias que tuvieron comporta-

3. GRAFTS, N.F.: British economy growth during the Industrial Revolution, Oxford, 1985; WrIGLEY, E. A.: Continuidad, cambio y azar, Barcelona, Editorial Crítica, 1993.

4. BERG, M,: «Mercados, comercio y manufactura europea», en BERG, M (Ed.): Mercados y manufacturas en Europa, Barcelona, Editorial Crítica, 1995, pág. 15.

5. Sólo como muestra citamos las siguientes obras que reflejan la inquietud en los estudios sobre estas formas económicas en transición: KRIEDTE, P.: Feudalismo tardio y capital mercantil. Líneas maestras de la historia económica europea desde el siglo XVI hasta finales del siglo XVIII, Barcelona, Crítica, 1982; DUPLESSIS, R. S.: Transiciones al capitalismo en Europa durante la Edad Moderna. Zaragoza, Prensas Universitarias de Zaragoza, 2001; BRENNER, R.: «Estructura de clases agraria y desarrollo económico en la Europa preindustrial»; en Aston T. H. y PHILPIN, C. H. E. (Eds.): El debate Brenner. Barcelona, Crítica, 1988, págs. 21-81; BRENNER, R.: «Auges y declives de la servidumbre en Europa durante la Edad Media y la Edad Moderna». Hispania, LVI, 192, 1996, págs. 173-201.

6. Yun CASAlilla, B.: «Mercado del cereal y burguesía en Castilla, 1750-1868. Sobre el papel de la agricultura en el crecimiento económico regional», en YUN CASALILLA, B. (Coord.): Estudios sobre capitalismo agrario, crédito e industria en Castilla (siglos XIX y XX), Salamanca, 1991, pág. 72.

7. Salvando las distancias, un caso muy parecido a Belfast en el siglo XVII. Esta población experimentó un crecimiento importante, en paralelo al desarrollo mercantil, y a la consolidación de una burguesía comercial que adquirió ciertas cotas importantes de poder: AGNEW, J.: Belfast merchant families in the Seventeenth century, Four Court Press, 1996.

8. Yun Casalilla, B.: Sobre la transición al capitalismo en Castilla. Economía y sociedad en Tierra de Campos (1500-1830), Valladolid, Junta de Castilla y León, 1987, pág. 524.

9. BERG, M,: «Mercados, comercio y manufactura europea...» op. cit. pág. 38. 
mientos claramente capitalistas en un universo social y económico agrario y ruraliza$\mathrm{do}^{10}$. Comportamientos capitalistas en un periodo de transición y cambio, pero que se empaparon de una realidad social concreta. En primer lugar, la realidad familiar. La familia, como célula básica de organización social y económica, regulaba gran parte del ritmo económico de esta comunidad mercantil. También insiste en ello Alberto Angulo, poniendo énfasis en la íntima relación que tuvo el parentesco en las esferas de lo privado y lo público dentro del marco social del comercio ${ }^{11}$. Y por otro lado, los lazos de amistad, solidaridad y cambios de favores, que se convirtieron en una parte muy importante de la estructura de los negocios comerciales ${ }^{12}$. Clientelas sociales, reciprocidades y mutuas dependencias se convirtieron en elementos trascendentales a la hora de comprender las acciones de los comerciantes, sus formas económicas y sus pautas de actuación social. Era una economía que comenzaba a tener importantes rasgos capitalistas, pero con un marcado peso de las relaciones sociales. Se estableció, de esta forma, una economía de la obligación ${ }^{13}$, en la que tuvo mucha trascendencia el crédito. Pero un crédito entendido como reputación social, con un significado mucho más complejo que el que actualmente se le otorga.

Un aspecto que no significa empequeñecer el crecimiento comercial, el desarrollo del mercado y los hábitos de consumo en ese último tercio del siglo XVIII. Sólo enriquecerlo con los matices adecuados de la esfera social donde éste se encuadraba. Toda dinámica de crisis o de crecimiento -señala José Ubaldo Bernardos ${ }^{14}$ - conlleva una transformación de los centros de actividad y del tipo de agentes que en ella intervienen. Eso fue lo que ocurrió en la villa de Albacete en el siglo XVIII, y especialmente su último tercio. Los centros de actividad económica a nivel comarcal cambiaron en sentido hacia esta población y sus agentes y actores sociales también. Pero esto sucedió dentro de una realidad económica concreta y unas prácticas sociales y culturales determinadas.

10. Ciertamente un comportamiento similar al que Miguel Ángel MELÓN JiMÉNEZ (Los orígenes del capital comercial y financiero en Extremadura: Compañias de Comercio, comerciantes y banqueros de Cáceres (1773-1836), Badajoz, 1992) ha establecido para las familias burguesas de Cáceres en el último cuarto del siglo XVIII y primer tercio del siglo XIX.

11. Angulo Morales, A.: Del éxito en los negocios al fracaso del consulado. La formación de la burguesía mercantil de Vitoria (1670-1840), Bilbao, Universidad del País Vasco, 2000, pág. 231.

12. Sobre esto ya insistía CASEY, J. y VINCENT, B.: «Casa y familia en la Granada del Antiguo Régimen», en CASEY, J et. at.: La familia en la España Mediterránea (siglos XVI-XIX), Barcelona, 1987, pág. 209

13. Muldrew, C.: The economy of obligation. The Culture of Credit and social relations in Early Modern England, Mac Millan Press, 1998.

14. Bernados SANZ, J. U.: Trigo castellano y abasto madrileño. Los arrieros y comerciantes segovianos en la Edad Moderna, Salamanca, Junta de Castilla y León, 2003, pág. 69. Sobre esta cuestión también: GARCÍA EsPuche, A.: Un siglo decisivo. Barcelona y Cataluña, 1550-1640, Madrid, Alianza, 1998. 


\section{FUENTES Y METODOLOGÍA: OBLIGACIONES Y RECONOCIMIENTOS DE DEUDAS}

Para abordar el complejo mundo de los intercambios comerciales, se ha recurrido al tratamiento sistemático de un tipo de escritura de protocolos notariales: las obligaciones $^{15}$. En total se han informatizado 664 obligaciones, de las que 574 son reconocimiento de deudas, algo más de 50 son obligaciones de recaudar ciertos impuestos, unas 21 escrituras son obligaciones de suministrar algún tipo de bien, y el resto no pueden ser clasificadas en ninguno de estas tipologías. Evidentemente, y pese a la importancia de las dos últimas, son los reconocimientos de deuda las escrituras más interesantes para aprehender el peso, volumen, densidad y los tipos de intercambios comerciales.

Para hacerlo de forma metódica se ha optado por realizar catas sistemáticas cada 10 años en todos los escribanos disponibles, y analizado un periodo intensivo entre 1780-1820. La intención era tener una muestra suficientemente representativa-temporal y cuantitativa- que pudiera reflejar el nivel del comercio en la villa.

El resultado de las escrituras obtenidas es visible en el siguiente gráfico. La mayor parte de las mismas - un 43\%- son las que proceden de compra-ventas de ganado, tanto mular como caprino y lanar. La trascendente presencia del comercio de la lana en la villa de Albacete ${ }^{16}$, y después de la extensión cerealícola que esta zona vivió a mediados del siglo XVIII creaba una demanda de fuerza de tiro - ganado mular- que favoreció esta orientación de las transacciones comerciales. El papel intermediador de la villa en la comarca manchega también explica este tipo obligaciones, pues muchas de ellas estaban orientadas hacia el mundo rural circundante. Del resto de transacciones hay que reseñar el mercado crediticio ${ }^{17}$, y los intercambios comerciales relacionados con el sector textil, entre los que hay que resaltar la lana ${ }^{18}$ y todos los géneros de vestidos lujosos traídos de Valencia y Cataluña. Como puede verse en el gráfico siguiente, entre ambas suponen casi un cuarto de todas las escrituras. Es necesario también reflejar el

15. Esta escritura también ha sido bastante utilizada por MELón JiMÉnEZ, M. A.: Los orígenes del capital comercial y financiero... op. cit.

16. En Vitoria, por ejemplo, son las transacciones de lana y de hierro las que más se efectuaban por la burguesía comercial de esta ciudad: Angulo Morales, A.: Del éxito en los negocios al fracaso del consulado... op. cit.

17. El crédito y la obligación son conceptos muy íntimamente unidos. La carencia de dinero líquido, y las necesidades en momentos dados de esto, obliga a la formalización de estas escrituras. Algo que tuvo mucho que ver con la proliferación de pleitos por la no devolución del dinero. Craig MULDREW (The economy of obligation... op. cit. pág. 4) así lo atestigua en el caso inglés: «when the litigation had reached its height and the concept of credit became pervasive in much discoverse, to the early eighteenth century. It was in this economic crucible that the maintenance of the social ethic of credit as trust became so important».

18. Sobre el mercado de la lana, Miguel Ángel MELÓN JiMÉNEZ (Los orígenes del capital comercial y financiero... op. cit. pág. 28) centra gran parte de su estudio sobre el comercio y comerciantes de Cáceres. Éste fue dominado primero por compañías comerciales provenientes de Sevilla y del extranjero, pero pronto estas compañías fueron sustituidas por otras cacereñas, que comenzaron a capitalizarlo y controlarlo. 
Gráfico 1. Tipos de obligaciones efectuadas en protocolos (Albacete, 1680-1830)

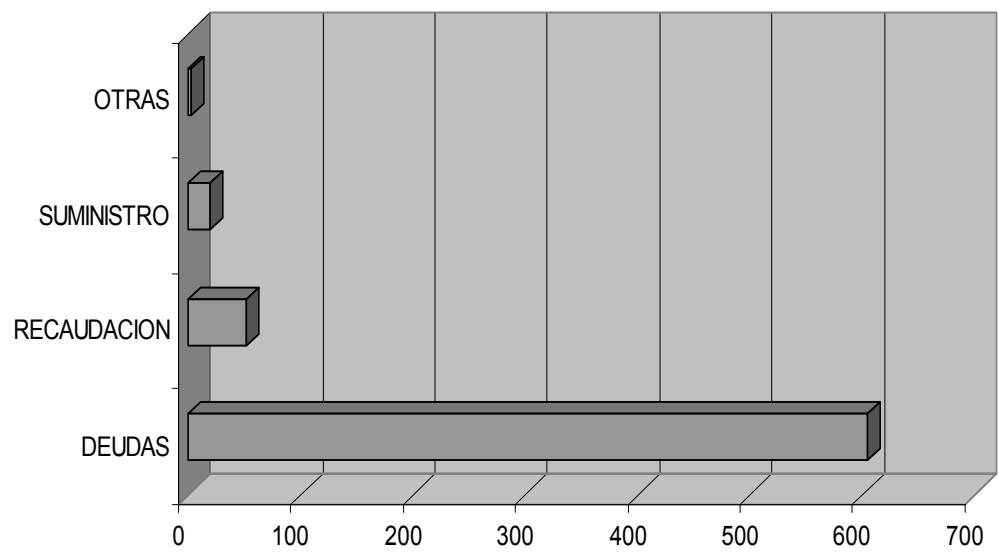

Gráfico 2. Tipo de deudas y número de escrituras

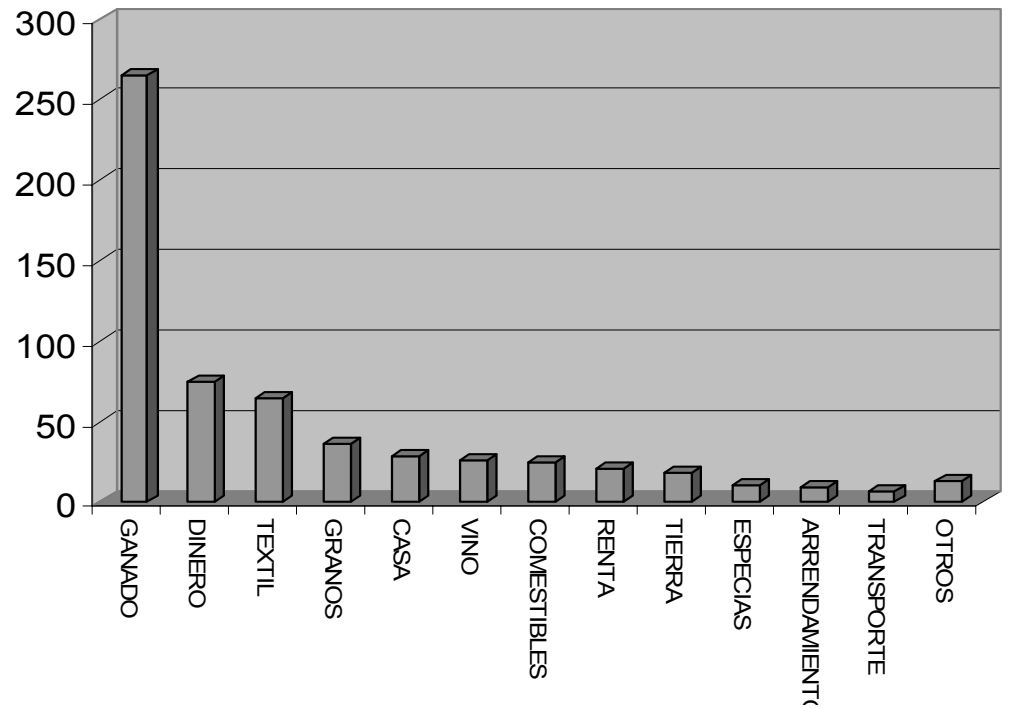

peso relativo que tienen el vino, comestibles y especias, de un $10 \%$ entre ellas. El resto representan un número más pequeño.

No obstante, si se observa el gráfico referido al valor de estas escrituras puede apreciarse un cambio significativo en el peso específico de los productos protagonistas de las transacciones. El comercio del ganado sigue teniendo un importante peso, que llega casi al millón de reales. Pero ahora sólo supone algo más del 30\% del valor de 


\title{
Gráfico 3. Porcentaje del número de escrituras según el tipo de deudas
}

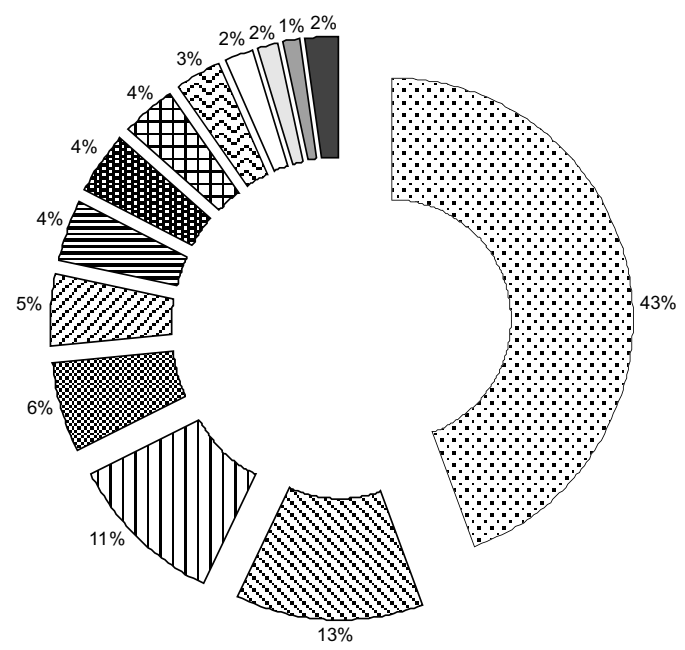

\author{
$\because$ GANADO \\ 3 DINERO \\ (1) TEXTIL \\ $\otimes$ GRANOS \\ 2 CASA \\ E $\mathrm{VINO}$ \\ 眮 COMESTIBLES \\ 田 RENTA \\ 9 TIERRA \\ $\square$ ESPECIAS \\ $\square$ ARRENDAMIENTO \\ TRANSPORTE \\ OTROS
}

los reconocimientos de deuda. Los bienes textiles y el comercio de granos ${ }^{19}$ son los que reflejan una mayor subida en porcentajes en relación valor-número de escrituras. Sin duda, fue el mercado del trigo uno de los que más se benefició de la mayor integración mercantil de la segunda mitad del siglo XVIII. A este respecto, Enrique Llopis y Sonia Sotoca señalan los vínculos estrechos que ya existían entre Murcia, Castilla-La Mancha y Castilla y León, y de éstos con Valencia y Andalucía ${ }^{20}$. Algo que propició la extensión del cultivo de cereales en la villa. Así, en los libros del pósito de la población de Albacete se aprecian constantemente las continuas entradas de trigo y granos entre el mundo rural circundante, comarcas conquenses, el puerto de Alicante y poblaciones murcianas $^{21}$.

El auge del comercio lanero francés ${ }^{22}$ y los contactos mercantiles franceses con Valencia influyeron, quizás, en la mayor importancia del valor de estas escrituras referentes a textiles. La lana y el azafrán fueron dos de los más importantes productos que se exportaban. Por el contrario, se produjo una gran importación de vestidos, telas y

19. Bernardos SANZ, J. U.: Trigo castellano y abasto madrileño... op. cit. pág. 14; señala en el caso de los arrieros y comerciantes de las localidades segovianas de Sangarcía y Etreros, cómo consiguieron una importante acumulación de capital, inusual en el medio rural castellano, gracias a ese comercio de granos y la legislación librecambista de 1765:

20. Llopis AngelÁn, E. y SotocA, S.: «Antes, bastante antes: la primera fase de la integración del mercado español del trigo», en Historia Agraria, n 36, 2005, pág. 235.

21. Los libros del pósito del siglo XVIII pueden consultarse en el Archivo Histórico Provincial de Albacete, y su referencias es la siguiente: AHPA Secc. Municipios, leg. 448 y 449.

22. Prados De La Escosura, L.:«Comercio exterior y cambio económico en España (1742-1849)», en Fontana, J. (Ed.): La economía española al final del Antiguo Régimen. III. Comercio y colonias, Madrid, 1982, págs. 173-249. 


\section{Gráfico 4. Tipo de deudas y valor de las mismas (Albacete, 1680-1830)}

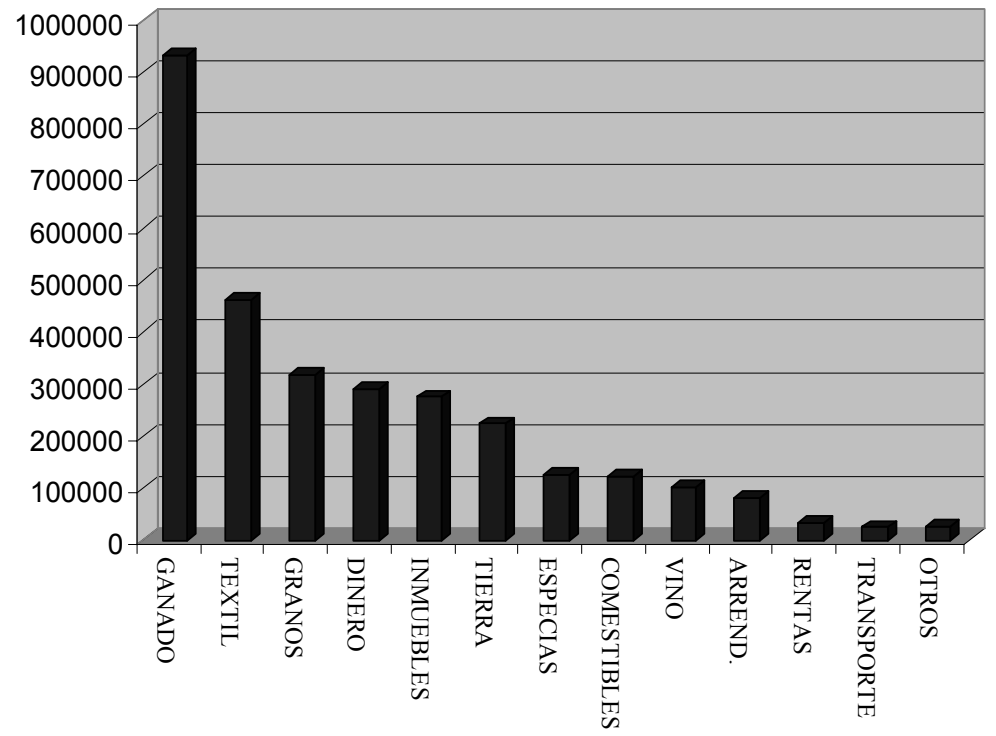

tejidos de carácter lujoso, algunos de ellos extranjeros que llegaron a través de Valencia, Murcia y Cataluña. El comercio de comestibles y vino tuvo un peso similar en su valor con respecto al número de escrituras. Eran, como en el caso que expone Bartolomé Yun para la Tierra de Campos, productos de consumo local o de lugares próximos ${ }^{23}$.

En el gráfico 5 puede verse el promedio del dinero de los reconocimientos de deudas. El incremento del dinero en las transacciones es bastante importante. Mientras que tras 1780 hay años que alcanzan más de 15.000 reales de media por deuda, e incluso 30.000, los años anteriores tienen una media ciertamente baja. Es evidente que ese incremento no sólo se debió al crecimiento económico de la villa, sino también al establecimiento en la misma de importantes comerciantes foráneos ${ }^{24}$. Pero también -cómo no- de los mayores y más intensos contactos mercantiles de la incipiente burguesía albacetense con compañías de comercio valencianas, murcianas, madrileñas, alicantinas y francesas. Éstas las colocaban en unas redes comerciales bien distintas a las que estaban presentes en los dos primeros tercios del siglo XVIII. La ausencia de intercambios con compañías de comercio, y el escaso radio de los intercambios en esos primero 60-70 años del siglo son significativos al respecto.

23. Yun CASAliLla, B.: Sobre la transición al capitalismo... op. cit. pág 534.

24. Algo parecido a lo que Miguel Ángel MELÓN JIMÉNEZ (Los orígenes del capital comercial y financiero... op. cit. pág. 28) ha constatado para Cáceres. El primer impulso importante del comercio estaba dominado por comerciantes y compañías comerciales foráneas. Hasta el último cuarto del siglo no se consolidó una burguesía comercial oriunda de esa población. 


\section{Gráfico 5. Promedio de dinero en las obligaciones por años (1680-1825)}

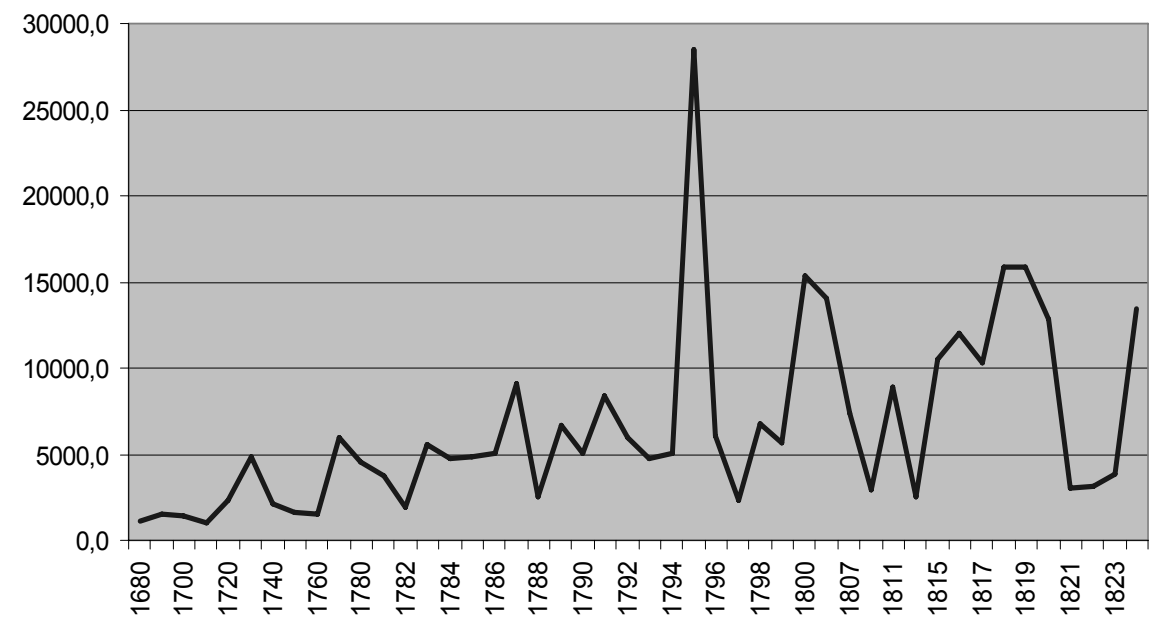

Como indica Alberto Angulo ${ }^{25}$ para el caso vitoriano, los vínculos generados por el mercado no se limitaban a dar cierta homogeneidad al grupo social burgués que en esos momentos se estaba consolidando, en este caso en la villa de Albacete. Además, este proceso ayudó a la aparición sistemática de redes de relación con otros grupos. En la mitad del siglo XVIII los comerciantes más importantes de esta población fueron Ignacio Suárez, Antonio Santos Cuesta y Miguel Sierra. Éstos actuaron de una forma muy individual y sin una importante integración social entre ellos. En el último cuarto del siglo pasó algo diferente. Las familias que en ese momento empezaron a controlar el comercio, las familias Serna, Parras, Torres, Herráez y Gómez, tuvieron una mayor cohesión social. Además, esto coexistió con la llegada de comerciantes foráneos, como Pedro Crespo, Bernardo Mulleras, Esteban Frigola, Audal y su hijo José Sabater. Se reforzaron los lazos y vinculaciones entre los comerciantes que partían de un componente claramente económico. Por supuesto. Pero todo esto alcanzó un carácter más amplio y complejo. Un matiz que podíamos considerar como plenamente social ${ }^{26}$. Evidentemente esto enriqueció el comercio de la villa, y nutrió el crecimiento económico de un componente que no tuvo en la centuria del Quinientos.

\section{LA INERCIA DE LA CRISIS Y LA RECUPERACIÓN. EL COMERCIO EN LA VILLA DE ALBACETE ENTRE 1680-1730}

Los años finales del siglo XVII y el primer tercio de la siguiente centuria se caracterizaron en la villa de Albacete por un periodo de inercia de la grave crisis que la población sufrió en el Seiscientos, pero con un tímido intento de recuperación y creci-

25. Del éxito en los negocios al fracaso... op. cit. pág. 271.

26. Ibidem, pág. 272. 
miento. Este intento - truncado por la Guerra de Sucesión pero retomado más tarde- dio sus frutos ya al final de este periodo, poniendo los cimientos del importante desarrollo económico y comercial de esta villa en la segunda mitad del siglo XVIII. Los años de la Guerra de Sucesión fueron más duros en la comarca de La Mancha que en el sur del Reino de Murcia. Según Guy Leumenier y María Teresa Pérez Picazo ${ }^{27}$ este periodo fue de reapertura de la economía murciana al mercado. Un «despertar económico» que tuvo que esperar unas décadas en la comarca manchega.

Si se observa la tabla siguiente se puede comprobar cómo fue el ganado y los créditos en dinero los que dominaron las transacciones, muy por encima de otros bienes o productos. Hay que esperar a que se produzca la expansión demográfica para comprobar el mayor desarrollo mercantil y de consumo ${ }^{28}$. Los bienes textiles ocuparon una posición muy rezagada y los granos y especias apenas tienen presencia en estos momentos.

Aunque seguía teniendo primacía la mula en el ganado de tiro, todavía existía una mayor diversificación en estas compra-ventas de ganado. Muestra de esta situación es la obligación que en 1680 hace Don Diego Cortés Alfaro, vecino de la aldea del Salobral, y en la que se declara deudor de Pedro de Orea por 403 reales. Esta cantidad era el resto de 750 por la compra de un rocín de pelo castaño ${ }^{29}$. También es el caso -en la misma fecha- de la que realiza Juan López Nieta, vecino de la villa de Peñas de San Pedro, que debe 572 reales a Bartolomé Cañavate por la compra de un potro de pelo castaño de 4 años de edad ${ }^{30}$.

Un asunto muy interesante es ver cómo en las compra-ventas que en ese momento se reflejan en estos reconocimientos de deuda, tienen un peso importante como vendedores los personajes de la élite social y los miembros de la Iglesia. Es el caso, por ejemplo, de la escritura de obligación que en 1690 realizó Miguel Verdejo, vecino de Jorquera, en la que declara deber 525 reales a Don Antonio Aparicio, presbítero de la villa de Albacete ${ }^{31}$. Esta deuda era por un par de bueyes de pelo castaño de 4 años de edad. También es significativa la obligación que realizaron conjuntamente Francisco Nieva y Andrés Villora, ambos de Albacete, en 1710 por una deuda de 837 reales. Ésta provenía de la compra de 21 arrobas de lana negra castellana a Don Juan Fernández Cortes, hidalgo también procedente de la villa de Albacete ${ }^{32}$.

27. PÉREZ PICAZO, Ma T. y LEMEUNIER, G.: El proceso de modernización de la región murciana (siglos XVI$X I X)$, Murcia, 1984, pág. 148.

28. A partir de entonces encontraremos un desarrollo del consumo y del mercado similiar al que MULDREW, C.: The economy of obligation... op. cit. pág. 16 ha estudiado en Inglaterra desde la mitad del siglo XVI hasta la mitad del siglo XVII sobre el proceso de crecimiento demográfico, de producción y de mercado.

29. AHPA Secc. Protocolos, leg. 3279 «Obligación de Diego Cortés Alfaro», fols 173-173v.

30. AHPA Secc. Protocolos, leg. 3279 «Obligación de Juan López Nieta», fols. 215-215v.

31. AHPA Secc. Protocolos, leg. 1004 «Obligación de Miguel Verdejo», fols. 147-147v.

32. AHPA Secc. Protocolos, leg. 1014 «Obligación de Francisco Nieva», fols. 57-57v. 
Tabla 1. Tipo de deudas (Albacete, 1680-1730)

\begin{tabular}{|c|c|}
\hline Tipo & Número \\
\hline Ganado & 46 \\
\hline Dinero & 23 \\
\hline Comestibles & 9 \\
\hline Textil & 8 \\
\hline Transporte & 3 \\
\hline Casa & 3 \\
\hline Vino & 2 \\
\hline Renta & 1 \\
\hline Misas & 1 \\
\hline Granos & 1 \\
\hline Especias & 1 \\
\hline
\end{tabular}

La naturaleza de los individuos que declaraban en estas escrituras es de un área de influencia pequeña. Es decir, los heredamientos, lugares y aldeas de la villa, las poblaciones de la actual provincia y algunas villas murcianas como Jumilla o Yecla. Pese a ello, es ciertamente interesante comprobar cómo no se paralizaron -en absoluto- los intercambios interiores y comarcales. Se ralentizaron debido a la crisis del Seiscientos -es cierto- pero nunca desaparecieron del todo, ni hubo un aislamiento total de las áreas rurales con respecto de las más urbanizadas ${ }^{33}$.

La mayoría de compra-ventas reflejadas en estos reconocimientos de deuda con deudores foráneos están relacionadas con el ganado. La orientación económica de la villa hacia la redistribución de la producción de ganado en dirección a las áreas rurales es bastante clara, incrementada además por la orientación económica de las élites locales albacetenses, y la falta todavía de un potente grupo comercial, como ocurrió a finales del siglo XVIII ${ }^{34}$. Las transacciones dominantes fueron las de la mula y los animales de tiro. Así, en 1710 Clemente Roldán, vecino de Quintanar del Rey, decía deber 1.160 reales, resto de una cantidad mayor por la compra de tres mulas. El vendedor fue Don Francisco Antonio Cerrillo, presbítero de la villa de Albacete, y como fiador de Clemente firmó Francisco López, labrador en el Heredamiento de La Lobera $^{35}$.

33. No tenemos una opinión tan catastrofista como apunta RINGROSE, D.: «In the early seventeenth century this integration [intercambios comerciales y redes mercantiles] of local and long-distance economies broke down, and regional isolation was intensified»: Madrid and the Spanish economy, 1560-1850, London, University of California Press, 1983, pág. 164.

34. Sobre la orientación económica de las élites albacetenses vid: MolinA PUCHE, S.: Familia, poder y territorio. Las élites locales del corregimeinto de Chinchilla-Villena en el siglo XVII, Tesis Doctoral, Murcia, 2005.

35. AHPA Secc. Protocolos, leg. 1014 «Obligación de Clemente Roldán», fols 12-12v. 
El ganado lanar y caprino tienen una menor presencia entre las obligaciones encontradas en las que los deudores son foráneos. Sólo podemos reseñar la obligación de Pedro Espinosa y Francisco Villaescusa en 1690, el primero vecino de Mahora y el segundo de La Gineta ${ }^{36}$. En ésta declaran deber al obispado de Cartagena 7.380 reales por la compra de 447 cabezas de ganado lanar y caprino realizada en las Tercias Decimales de la villa de Albacete.

El resto de bienes, como en el conjunto de las obligaciones de este periodo, son minoritarios. Destaca el papel de redistribuidor de productos alimenticios a las poblaciones rurales. Es el caso de la obligación en 1710 de Miguel Gómez Valera ${ }^{37}$, vecino de Madrigueras. En ella reconoce deber a Pedro de Orea 750 reales por la compra de una partida de tocino, al parecer para la tienda que éste tiene en esa población. También en el caso del vino. Así, Francisco Encina, vecino de Chinchilla, hace una compra en 1.680 de 50 arrobas de vino tinto por el precio de 602 reales a Juan Cano Picazo, procurador de causas de la villa de Albacete ${ }^{38}$.

Algo diferente es la naturaleza de los acreedores foráneos que aparecen en la muestra que se ha realizado. Esto apunta a una diferente tendencia en la que los compradores -en general- son los vecinos de Albacete, y tienen transacciones con lugares más alejados ${ }^{39}$. Ya entonces comenzó a aparecer esta diferente forma de actuación en la que también cambian los productos protagonistas en estas transacciones.

Interesante es el caso de los carreteros oriundos de Yecla que traían en 1680 cargas de papel del puerto de Alicante. En su paso por la villa de Albacete con la intención de comerciar con ese bien, se obligaban a pagar la renta que por ello se gravaba. Así, los hermanos Cosme y Miguel Azorín reconocían deber a Don Pedro Bonilla Malo, vecino de Madrid, y Administrador de la Renta de papel, 2.770 reales que les correspondía por 6 carros que traían de la ciudad portuaria alicantina ${ }^{40}$. Esto demuestra la vitalidad del camino que unía estas villas interiores con el Mediterráneo ya en tempranas fechas. Si bien es verdad que todavía no comenzó a funcionar como en años posteriores, también lo es que era una vía fundamental de comercio.

En conclusión, este periodo de finales del siglo XVII y primer tercio del siglo XVIII fue un momento en el que se iba superando el periodo de crisis de mediados de la centuria del Seiscientos. Los intercambios comerciales eran pocos y de muy corto recorrido. Pero no por ello nulos. Gran parte de todas las obligaciones estaban protagonizadas por algún personaje foráneo de la villa propiamente dicha. El círculo del mercado en esos momentos era bastante reducido: las aldeas, lugares y heredamientos del alrededor. Las villas de la provincia, y algunas de Cuenca próximas, como Sisante, la propia Cuenca o Quintanar del Rey. Hay que recordar que la inmigración que tenía

36. AHPA Secc. Protocolos, leg. 1004 «Obligación de Pedro Espinosa», fols. 84-84v.

37. AHPA Secc. Protocolos, leg. 1014 «Obligación de Miguel Gómez Valera», fols. 2-2v.

38. AHPA Secc. Protocolos, leg. 3279 «Obligación de Francisco Encina», fols. 61-61v.

39. Lo que todavía pone más en tela de juicio ese aislacionismo que David RINGROSE (Madrid and the

Spanish ... op. cit. pág. 165) apunta para el interior castellano a partir en el siglo XVII.

40. AHPA Secc. Protocolos, leg. 3279 «Obligación de Cosme Azorín», fols. 306-306v. 
como destino la población de Albacete provenía en su mayoría del norte de la actual provincia de Albacete y el sur de la provincia de Cuenca. A estos lugares los complementaban las villas murcianas de camino hacia el Mediterráneo -Yecla y Jumilla- y Cartagena por la venta del ganado de las Tercias Decimales y que correspondían al Obispo y al Deán.

En vista de esta situación, el tipo de transacciones venía condicionado por el escaso desarrollo de los grupos de comerciantes que por entonces habitaban en la villa ${ }^{41}$. Así, los grupos de la élite y los eclesiásticos eran los protagonistas en los intercambios de bienes de consumo. Unos bienes poco lujosos que tenían en el ganado, la lana, el mercado crediticio y los alimentos, sus principales factores.

\section{LOS PILARES DEL CRECIMIENTO (1740-1780)}

Después de superar el estancamiento del siglo XVII y de la Guerra de Sucesión, los años 30' y 40', y hasta la década de 1780 del siglo XVIII se caracterizaron por un importante crecimiento demográfico. Un síntoma inequívoco del despegue económico de la villa albacetense. Muchos indicadores lo muestran. El principal, el incremento importantísimo de los índices de bautismos y matrimonios. Pero también muchos otros. En 1735 todavía las personas que vivían del comercio en la población lo hacían con una actividad poco especializada y sofisticada. La mayoría de ellos eran arrieros, a los que completaban algunos tenderos y mesoneros. En 1761, por el contrario, existen muchas y más variadas situaciones socio-económicas de estos comerciantes que incitan a pensar en un cambio que se produjo en ese segundo tercio del siglo. Tratantes, comerciantes, y mercaderes se mezclaban con arrieros, carreteros, tenderos, confiteros y mesoneros. Un mercado más diversificado, especializado y de más alto standing, que se tradujo en un interesante incremento del prestigio social de muchas familias de mercaderes que actuaron en los años centrales del siglo. Ignacio Suárez, Miguel Sierra, José García Malo Molina y Antonio Santos Cuesta tuvieron unos negocios comerciales ciertamente importantes que introdujeron a la villa en más vastas redes comerciales de las que antes estaba inmersa. Redes que supusieron -sin duda - la base para esa explosión del comercio en los 20 últimos años del siglo, y en la movilidad social ascendente de muchos comerciantes en los años finales del Antiguo Régimen.

Los tipos de deudas contraídas en este momento marcan todavía un proceso intermedio entre lo que se produjo en el anterior periodo y el que se vivió a finales del Antiguo Régimen. El mercado crediticio y el ganado seguían teniendo la primacía de las transacciones en ese momento. Pero ahora aparecen con más importancia el mercado de granos, de textiles, de especias y comestibles. Esto es muestra del mayor

41. En comparación con esta situación, Alberto ANGULO MORALES (Del éxito en los negocios al fracaso... op. cit. pág. 91) señala que los comerciantes que se asentaron en Vitoria a mediados y finales del siglo XVII no lo hicieron con ninguna casa mercantil formada. Habría que esperar a más adelante para el desarrollo más amplio de estos sectores bajo formas organizativas y relacionales más complejas. 
peso que tuvieron unas transacciones comerciales más especializadas. Además, su valor monetario por término medio era bastante superior. Pero lo más importante es la presencia de un mayor número de transacciones con mercaderes y compañías de comercio de otras ciudades. Es el caso, por ejemplo, de la obligación que en 1752 firmó José García Malo Molina ${ }^{42}$, en la que reconoce deber a Agustín Grima 7.400 reales que éste le ha prestado. El motivo del préstamo es el dinero que José García Malo debe por varias transacciones con un importante comerciante de Hellín. El mercader albacetense debía a Don Domingo Bauchon la cantidad nada despreciable de 53.970 $0^{43}$ reales. Tras no haber pagado dicha cantidad, José García fue embargado de sus bienes y llevado a presidio. Después de la mediación de algunos personajes principales de la villa se consiguió un convenio con el comerciante de Hellín. Así, se pudo partir la deuda en varios pagos durante un año, y de esta forma el mercader albacetense pudo recuperar sus bienes. Lo cierto es que uno de los productos de mercadeo que estaba encumbrando a estos comerciantes era el azafrán. José García así lo hacía, pues trataba con este bien hacia Valencia, Alicante y Murcia. Muestra de esto es la compra de este producto que hace en una obligación firmada ese mismo año de 1752. En ella declaraba deber a José Vila, procurador de causas de la villa albacetense, 3.300 reales por 84 libras de azafrán tostado $^{44}$.

Uno de los elementos más importantes en este momento es la mayor presencia de comerciantes y tratantes en estas transacciones, frente al clero y la hidalguía, mayoritaria en el periodo anterior. Así, tenemos la escritura de Juan Torres, en ese momento tendero, en la que declaraba deber en 1740 cierta cantidad por la compra de vino tinto. El precio fue 2.027 reales y la cantidad de vino fue 368 arrobas y 9 azumbres $^{45} .244$ arrobas y 4 azumbres a 6 reales cada una (las de vino de mayor calidad) y 124 arrobas y 5 azumbres a 4 reales y medio cada arroba (las de vino de una calidad inferior). Esta compra la hizo a Don Francisco Alfaro Munera, Administrador en ese momento de las Tercias Decimales del Partido de San Clemente. También está el caso en el mismo año de 1740 de Francisco Moreno, tendero, por la compra de lana. Éste declara deber 1.213 reales por 42 arrobas, 8 libras y 5 onzas de lana parda ${ }^{46}$. La persona a la que debía pagar en este caso fue, al igual que en la anterior, Don Francisco Alfaro Munera.

42. AHPA Secc. Protocolos leg. 3297 «Obligación de José García Malo Molina».

43. AHPA Secc. Protocolos, leg. 3297 «Escritura de convenio y obligación de José García Malo Molina».

44. AHPA Secc. Protocolos, leg. 3297 «Obligación de José García Malo Molina».

45. AHPA Secc. Protocolos, leg. 3293 «Obligación de Juan Torres», fols. 142-143v.

46. AHPA Secc. Protocolos, leg. 3293 «Obligación de Francisco García», fols. 107-107v. 
Tabla 2. Tipo de deudas (Albacete, 1740-1780)

\begin{tabular}{|c|c|}
\hline Tipo & Número \\
\hline Dinero & 28 \\
\hline Ganado & 21 \\
\hline Casa & 7 \\
\hline Granos & 6 \\
\hline Vino & 6 \\
\hline Textil & 5 \\
\hline Comestibles & 4 \\
\hline Especias & 4 \\
\hline Tierra & 4 \\
\hline Otros & 6 \\
\hline Transporte & 2 \\
\hline
\end{tabular}

El mercado crediticio estuvo bastante presente en este periodo. Fue un momento de grandes cambios para la población. El momento extensivo del cultivo, tanto a nivel cerealícola, como de viñedos y azafrán, exigía dinero líquido para su inversión. También las actividades comerciales necesitan de iniciales inversiones monetarias para llevarlas a cabo. La actividad de préstamos entre comerciantes ya asentados y aquéllos que intentaban consolidarse también es visible en este momento ${ }^{47}$. Ejemplo de ello es el caso del carretero Francisco Zafrilla, que firmó una obligación a finales del año de 1760. En ella declara deber a Juan Torres Arias, comerciante y procurador de causas, la cantidad de 7.200 reales que éste le ha prestado ${ }^{48}$. También es habitual los préstamos de dinero líquido de comerciantes a personajes de la élite que necesitaban en muchas ocasiones de este bien para pleitear por los bienes que habían quedado de herencias. Es el caso de la deuda que declara Don Antonio Carrasco Castro en 1766 para los pleitos que lleva en Madrid para conseguir unos vínculos de la rama familiar de su esposa, Doña Eustaquia Rocamora Piquinotti. El acreedor en este caso fue también Juan Torres Arias, que le prestó 5.300 reales al contado.

Como se ha comentado, el comercio de granos fue perfilándose en ese momento. La extensión de este tipo de cultivos a partir de los años 30' del Setecientos, así como el impulso de la carretera de Madrid hacia Levante, favoreció un mayor número de transacciones de este tipo. Así, Juan de Abia, carretero, firmó una escritura de obligación en 1780 por esta cuestión. En ella declaraba deber cierta cantidad numeraria a Francisco Herráez Gascón, comerciante de granos y otros géneros, por 40 fanegas de cebada que

47. Como señala Michel ZYLBERBERG («Un centre financier «péripherique»: Madrid dans la seconde moitié du XVIIIe siècle», en Revue Historique, 546, pág. 288) en el caso madrileño de la segunda mitad del siglo XVIII, es raro el comerciante que perteneciera a los Cinco Gremios Mayores que no hubiera realizado la usura.

48. AHPA Secc. Protocolos, leg. 1026 «Obligación de Francisco Zafrilla», fols. 231-231v. 
éste le suministró ${ }^{49}$. Pero fue el trigo el mayor protagonista de las transacciones por el comercio de granos. Así, Miguel Monteagudo, labrador y carretero se obligaba a pagar 34 fanegas y 8 celemines de trigo que sacó del pósito público en $1760^{50}$. Hay que tener en cuenta que a mediados de la década de 1760 fue cuado se promulgó la Pragmática de Libre Comercio que alteró el marco - como señala José Ubaldos ${ }^{51}$ - en el que se desenvolvía la política de abastecimiento y el mercado interior.

Sin embargo, el ganado seguía siendo el principal objeto de estas transacciones. Seguía la dualidad entre el ganado de tiro -ahora ya sí completamente dominado por la mula- y el ganado lanar y caprino. Mientras que el primero era consecuencia de una transacción entre dos particulares, el segundo solía derivar de las ventas que se hacían en las Tercias Decimales. Ejemplo de esto último es la compra de este tipo de ganado que realizó Jorge García en 1740. Éste declaró deber a Don Francisco Alfaro Munera 4.432 reales por 277 cabezas de ganado lanar y caprino. En cuanto al caso primero, al del ganado de tiro, la transacción que firmó José Moreno a través de una escritura de obligación es ejemplo de ello. En este documento, éste decía deber a Pascual Vergara, vecino de Jorquera, la cantidad de 1.450 reales por una mula que éste le vendió ${ }^{52}$.

\section{LA ÉPOCA DE EXPLOSIÓN COMERCIAL (1781-1830)}

El momento de mayor movimiento comercial en la villa fue el que correspondió a los 20 últimos años del Setecientos y tras pasar las crisis de los primeros años del siglo $\mathrm{XIX}^{53}$. El establecimiento de la Feria Franca en la población, la inercia de crecimiento demográfico, la extensión de la red de tiendas, el mayor número de comerciantes al por mayor ${ }^{54}$, y el asentamiento de comerciantes catalanes y franceses en la villa son muestra de esto. Al igual que en Murcia, la presencia de comerciantes y artesanos galos es significativa ${ }^{55}$. Si bien para la región murciana eran agentes de grandes compañías para establecer filiales, en Albacete estuvo muy unido a los mercaderes franceses que se establecieron en Valencia. Algunos de estos negociantes han sido estudiados por

49. AHPA Secc. Protocolos, leg. 1029 «Obligación de Juan de Abia», fols. 144-144v.

50. AHPA Secc. Protocolos, leg. 1024 «Obligación de Miguel Monteagudo», 16/05/1760.

51. Trigo castellano y abasto madrileño... op. cit. pág. 165.

52. AHPA Secc. Protocolos, leg. 1029 «Obligación de José Moreno», fols. 96-96v.

53. Este comercio está en correspondencia con el auge que NAVARRO MIRALLES, J. L. «Contactos comerciales entre el litoral catalán -costas, norte del corregimiento de Tarragona y corregimiento de Villafranca del Penedés- y Puertos de Andalucía (1799-1808)», Actas del I Congreso de Historia de Andalucía. Andalucía Moderna (siglo XVIII). Tomo II, Córdoba, 1978; otorga a los contactos comerciales catalanes con los puertos andaluces de ese momento, y que se corresponde con un impulso comercial del último tercio del siglo XVIII:

54. AGNEW, J.: Belfast merchant families... op. cit indica para el caso de Belfast que el rápido crecimiento y prosperidad de este puerto comercial es reflejo del crecimiento de la comunidad mercantil.

55. Lemeunier, G. y PÉREZ PiCAZO, M $\mathrm{M}^{\mathrm{a}}$ T.: El proceso de modernización de la región murciana ... op. cit. pág. 193. 
Tabla 3. Tipo de deudas en la villa de Albacete (1781-1830)

\begin{tabular}{|c|c|}
\hline Tipo & Número \\
\hline Ganado & 202 \\
\hline Textil & 55 \\
\hline Granos & 29 \\
\hline Dinero & 24 \\
\hline Vino & 18 \\
\hline Casa & 17 \\
\hline Renta & 15 \\
\hline Tierra & 14 \\
\hline Comestibles & 12 \\
\hline Arrendamiento & 9 \\
\hline Especias & 6 \\
\hline Tinte & 2 \\
\hline Transporte & 2 \\
\hline Inmueble & 1 \\
\hline Artesano & 1 \\
\hline Convento & 1 \\
\hline Almotacen Y Correduria & 1 \\
\hline Hierro & 1 \\
\hline Monja & 1 \\
\hline Oficio & 1 \\
\hline Paja & 1 \\
\hline Salario & 1 \\
\hline Testamento & 1 \\
\hline Herencia & 1 \\
\hline & \\
\hline & \\
\hline & \\
\hline
\end{tabular}

Ricardo Franch Benavent ${ }^{56}$, como Galvien o Pelussier, y son importadores de tejidos del país francés.

Sin duda fue un momento trascendental en la población albacetense. En el siglo XVI existió un importante crecimiento económico y demográfico en la villa, pero las bases fueron diferentes al que se experimentó en el siglo XVIII. En el Quinientos, la expansión de la producción a través de las roturaciones extensivas de un terreno todavía poco cultivado y recientemente repoblado, y la extensión del ganado lanar y de la producción de lana ayudaron a la expansión de la villa. Pero el derrumbe del siglo XVII demostró que las bases sobre las que se sustentó ese crecimiento eran muy débiles. Sin embargo, el desarrollo del siglo XVIII superó crisis tan agudas como la de 1765-1766, las de 1804-1805, las de la Guerra de la Independencia y las que se produjeron en los años 30' del siglo XIX por la Guerra Carlista. El desarrollo de la villa se produjo sobre

56. Crecimiento económico y enriquecimiento burgués... op. cit. 
una base más sólida y con una posición mucho más central en la economía del país. En estos momentos se reforzó su papel de cruce de caminos entre Madrid y la periferia. Pero también - no hay que olvidar- las familias que se consolidaron con este crecimiento lo hicieron de forma muy distinta ${ }^{57}$.

Si se observan los tipos de reconocimientos de deuda que en este trascendental momento se realizan, las diferencias son notables. El ganado sigue siendo el motivo principal de las obligaciones, pero ahora muy seguido por los bienes textiles ${ }^{58}$ y por el comercio de granos. El mercado crediticio queda bastante reducido y los comestibles, las especias y el vino ahora lo superan ampliamente en conjunto. El resto, como consecuencia de la amplia muestra que se ha elaborado de este momento, refleja una gran variedad de transacciones. Muestra de esa variedad es la obligación que en 1791 firma José Millé, comerciante de origen valenciano, pero asentado en la villa de Albacete, en la que dice deber 30.000 reales al Ayuntamiento de la villa de San Clemente para recaudar la entrada a una corrida de toros que se celebraría en dicha villa ${ }^{59}$.

El ganado seguía siendo el bien más prolífico en estas transacciones, aumentado quizás por el establecimiento de la feria en Albacete, que prodigó la presencia de tratantes de la zona manchega para la venta de este bien a las poblaciones de alrededor. De hecho, Quintanar del Rey seguía siendo un origen muy habitual de los vendedores de ganado, al igual que Casas Ibáñez o Jorquera. Pero también, cómo no, entre los propios labradores y tratantes de la villa. Es el caso de la obligación que protagoniza Francisco Sarrión, carretero, en 1792. Así, éste declara que Andres Carrasco, mesonero, le vendió dos mulas por la cantidad de 4.000 reales $^{60}$. Y también siguió realizándose asiduamente la venta de ganado lanar y caprino a través de los bienes que salían en venta en las Tercias Decimales. Muestra de esta situación es la obligación que en 1782 protagonizó Manuel Luján, vecino de La Herrera, por la compra de 140 cabezas de ganado lanar y caprino $^{61}$.

57. Un ejemplo algo parecido es Santander, donde se desarrolló una burguesía mercantil como consecuencia del impulso económico y demográfico de esta ciudad entre 1750-1850 diferentes a la del siglo XVI: MARURI VILlANUEVA, R.: «Vestir el cuerpo, vestir la casa. El consumo de textiles en la burguesía mercantil de Santandr, 1750-1850», en TORRAS I ELÍAS, J. y Yun, B.: Consumo, condiciones de vida y comercialización. Cataluña y Castilla, ss. XVII-XIX, Valladolid, Junta de Castilla y León, 1995, pág. 160.

58. Lidia TORRA («Pautas de consumo textil en la Cataluña del siglo XVIII. Una visión a partir de los inventarios post-mortem», en TORRAS I ELÍAS, J. y YUN, B.: Consumo, condiciones de vida y comercialización. Cataluña y Castilla, ss. XVII-XIX, Valladolid, Junta de Castilla y León, 1995, pág. 96) indica en su estudio de las pautas de consumo en Cataluña cómo el número medio de piezas de ropa se incrementó en la segunda mitad del siglo XVIII con respecto a la primera, sobre todo en las localidades más urbanizadas, y con un mayor crecimiento como Mataró.

59. AHPA Secc. Protocolos, leg. 1032 «Obligación de José Millé», fol. 13v.

60. AHPA Secc. Protocolos, leg. 1035 «Obligación de Francisco Carrión», fols. 37-37v.

61. AHPA Secc. Protocolos, leg. 3314 «Obligación de Manuel Luján», fols. 80-80v. 
Especial relevancia hay que otorgar a las transacciones de bienes textiles, sobre todo por su alto valor ${ }^{62} \mathrm{y}$ por su significación comercial, al menos en este periodo. Muchas veces con el nombre genérico de «vestidos, telas y otros géneros de mercaduría», pero en otras ocasiones con denominaciones más específicas, estas escrituras reflejan las más hondas relaciones comerciales de los mercaderes albacetenses y las complejas redes mercantiles donde se asentaron. Un ejemplo de esto es la escritura que firmó Pedro Juran, comerciante albacetense, creemos que de origen catalán, por unos géneros textiles en 1785. Éste declaraba deber a José Soler Fos, comerciante valenciano, 5.097 reales, resto de una compra de géneros textiles que el mercader albacetense ha adquirido de la lonja de José Soler. Para esto expone los vales de compra donde se enumeran los géneros adquiridos: «un vale de 16 varas de terciopelo liso, otro vale por distintos géneros de ropa, 85 varas de cinta negra ancha de raso, 12 pañuelos de 4 fajas, 19 pañuelos de 4 fajas y 9 más $\rangle^{63}$. Algo que muestra -en concordancia con lo explicado por Máximo García Fernández ${ }^{64}$ - cómo la propiedad de un número cada vez mayor de piezas textiles, de mayor calidad y variedad en las familias más privilegiadas del sector mercantil, fue uno de los factores de transformación del mercado.

Muchas escrituras se han encontrado de este tipo, sobre todo con comerciantes valencianos, muchos de ellos de origen francés, y con compañías de comercio. Pero el mercado de textiles tiene también mucha variedad ${ }^{65}$. La obligación de José Cuesta, tejedor, sobre la compra en 1789 de 650 pieles es un buen ejemplo. Éste dice en la escritura que debe a José Torres y Diego Serna, ambos comerciantes, y que controlaban el abasto de carne y las pieles de cordero que se desechaban de la carnicería, la cantidad de 13.325 reales $^{66}$.

También existen escrituras que reflejan la venta de los bienes textiles traídos desde la periferia mediterránea, que se distribuyeron desde la villa de Albacete hacia otros lugares más lejanos de esta carretera. Es el caso de la deuda que Ramón Antonio Fuente, vecino de Villanueva de los Infantes en Ciudad Real, dice tener con la Compañía de comercio albacetense de Don José Sabater y su padre Audal en 1807. La deuda asciende a 2.832 reales y se corresponde con distintas ropas que Antonio Fuente adquirió del vecino albacetense ${ }^{67}$. La compañía de comercio formada por los Sabater

62. El aumento del valor de los textiles ya ha sido también comprobado por ROCHE en París: La culture des apparences. Une histoire du vêtement XVII-XVIII siècle, Fayard, 1989, pág. 110.

63. AHPA Secc. Protocolos, leg. 1031 «Obligación de Pedro Juran», fols. 19-19v.

64. GARCÍA FERNÁNDEZ, M.: «Los bienes dotales en la ciudad de Valladolid, 1700-1850. El ajuar doméstico y la evolución del consumo y la demanda», en TORRAS, J. y Yun CASAlilla, B.: Consumo, condiciones de vida y comercialización... pág. 140.

65. Según Lidia TORRA («Pautas de consumo textil en la Cataluña del siglo XVIII...» op. cit. pág. 89) la expansión de la demanda de textiles en el siglo XVIII debe situarse en el contexto del importante crecimiento demográfico y la coyuntura económica marcada por la expansión de la industria manufacturera y las actividades mercantiles.

66. AHPA Secc. Protocolos, leg. 1031 «Obligación de José Cuesta», fols. 95-95v.

67. AHPA Secc. Protocolos, leg. 1039 «Poder de José Sabater», fols. 44-44v. 
tenía en su tienda ropas de algodón traídas de Cataluña, por lo que probablemente fue ésta la causa de la deuda.

El comercio con Valencia, Alicante y Murcia se complementaba con el que se realizaba con Madrid. De las noticias que se tienen a través de estas escrituras parece que el negocio de textiles con la capital madrileña es sobre todo con paños y tejidos de lana y seda ${ }^{68}$. Así, Don Pedro Crespo, mercader de Albacete y el comerciante Antonio Baldos -también afincado en Albacete- firmaron una escritura de obligación en 1789. En ésta declaran deber a los Señores Torre y Teja de la Compañía de Paños de Madrid, la cantidad de 18.000 reales por distintos géneros que de su lonja han adquirido ${ }^{69}$.

El comercio de granos, que ya se estaba perfilando en los años anteriores, ahora adquirió más relevancia. En 1818 existe una importante deuda del comerciante albacetense Mariano González Mayor, que adquirió a principios del siglo XIX una gran cantidad de granos para comerciar, pero que no pudo satisfacer a causa de que perdió gran parte. Así, firmó una escritura en ese año de 1818 en el que se obligaba a pagar 55.000 reales, en cinco plazos de 11.000 cada uno, a Don Mariano Melgosa, Administrador del Crédito Público ${ }^{70}$. También en esa fecha existe una escritura que refleja una importante compra de trigo por un tratante de la villa. Esta vez Lucas Parras, importante tratante, con amplias relaciones de parentesco con la cúpula comercial de la villa. Éste realiza una compra de trigo a un comerciante murciano. Así, en la escritura declara deber a Don José Sala Can la cantidad de 15.000 reales procedentes de una porción importante de trigo ${ }^{71}$.

Lo más habitual era la compra de granos de carreteros y labradores de la villa y de comerciantes propiamente dedicados a eso, como Francisco Herráez Gascón, a través de las Tercias, o entre los labradores, los carreteros y comerciantes. De esta forma Juan de Abia y Antonio López, alpargateros ambos, hacen una compra de una porción de granos y algunos comestibles a dos comerciantes albacetenses en 1788. Éstos declaran deber a Francisco Herráez Gascón y Antonio de Tevar, tratantes de granos, la cantidad de 6.691 reales por 43 fanegas y un celemín de trigo candeal, 20 fanegas y 8 celemines de cebada, 8 libras y media de miel, 56 arrobas de bajocas y 53 fanegas y media de guijas $^{72}$. Al igual que indica Miguel Ángel Melón para Cáceres ${ }^{73}$, los años finales del siglo XVIII y el primer tercio del siglo XIX, coincidiendo con el asentamiento y despegue de la burguesía agraria, tiene lugar una racionalización de las actividades comerciales.

68. En todo caso, a la importación de tejidos de seda de Valencia se contrarrestaba una exportación de lana en bruto. Sobre la exportación de lana desde Valencia vid: FRANCH BENAVENT, R.: «Los comerciantes valencianos y el negocio de exportación de la lana en el siglo XVIII», en GonZÁLEZ ENCISO, A.: El negocio de la lana en España (1650-1830), 2001, págs. 201-234.

69. AHPA Secc. Protocolos, leg. 3316 «Obligación de Pedro Crespo», fols. 19-19v.

70. AHPA Secc. Protocolos, leg. 3318 «Obligación de Mariano González», fols. 214-216v.

71. AHPA Secc. Protocolos, leg. 3318 «Obligación de Lucas Parras», fols. 152-152v.

72. AHPA Secc. Protocolos, leg. 1031 «Obligación de Juan de Abia», fols. 1-1v.

73. Los orígenes del capital comercial y financiero en Extremadura ... op. cit. pág. 53. 
Éstas, por supuesto, tuvieron consecuencias positivas en la organización de mercados y en la agilización de intercambios a nivel regional.

El comercio del vino, comestibles y especias tiene ahora cierta importancia. A veces vienen todos estos bienes en conjunto, como la escritura de obligación que realiza el mercader Miguel Sierra Molina. Éste era hijo del ya mencionado Miguel Sierra, importante comerciante de mediados del siglo XVIII en Albacete. Este tratante declara deber a José Torres, comerciante y tendero, 4.500 reales por diferentes bienes, algunos comestibles y otros no, y los cuales enumera: «40 libras de cacao a precio de 5 reales y 3 cuartillos, 13 arrobas y media de azúcar terciada, 15 arrobas de garbanzos crudos, 234 arrobas de vino tinto, 33 varas de paño pardo, dos varas de indiana, 3 pañuelos de seda, media libra de hilo blanco y 22 reales en dinero» ${ }^{74}$. Con esto se muestra la diversificación de los bienes que se encontraban en las tiendas. Esa mezcla de especias, legumbres, vino, y prendas más o menos lujosas ${ }^{75}$ es reflejo de la también diversificación económica de estos comerciantes.

En las deudas sobre comestibles hay que señalar especialmente a la carne como una de la que más ha llegado a la escrituración en obligaciones. Sobre la carne solía haber un monopolio en torno a unos comerciantes que debían suministrar este bien a las carnicerías de la villa, incluso de algunas de alrededor. En 1817, por ejemplo, el abasto de la carne la consigue Juan Herráez. Éste, mediante una escritura de obligación, se obligaba ante el ayuntamiento a suministrar la carne de carnero, de oveja y de macho cabrío ${ }^{76}$. También está el caso de Francisco Gómez y Asensio Cuesta, los cuales era abastecedores de carnes para la villa albacetense en 1782, y protagonizan una escritura de obligación en la que compran una partida de carne. En ella decían deber a Juan Carrasco, abastecedor de carnes en La Roda, 3.000 reales por la carne que este les debía suministrar de las carnicerías de dicha villa manchega ${ }^{77}$.

Otro de los géneros que suele aparecer con asiduidad en estas escrituras es el bacalao. Éste, suministrado generalmente desde Alicante, solía ser comprado por los tenderos de la villa y tratantes de la misma para su redistribución a la población, puesto que era un bien muy difícil de conseguir en esta villa. Un ejemplo es la compra que en 1790 realiza Juan Molina Sanz, tratante albacetense, a Don Vicente Yañez, comerciante de Alicante, por una partida de bacalao. El primero declara deber al segundo 1.200 reales por dicho bien ${ }^{78}$. Muestra también de la distribución de esos productos a las villas cercanas es la escritura del comerciante albacetense Alonso Pascual con un vecino de La Gineta en 1789. Juan Candelas Mayor, vecino de esa villa manchega

74. AHPA Secc. Protocolos, leg. 3315 «Obligación de Miguel Sierra Molina», fols. 71-71v.

75. Sobre los bienes lujosos, el consumo de éstos como un modo de producción y circulación, así como su importancia en el mercado y las posibilidades de cambio que generan: FINE, B. y LEOPOLD, E.: The world of consumpltion, London, 1993.

76. AHPA Secc. Protocolos, leg. 3318 «Obligación de Juan Herráez», fols. 159-160.

77. AHPA Secc. Protocolos, leg. 1034 «Obligación de Francisco Gómez», fols. 42-42v.

78. AHPA Secc. Protocolos, leg. 1035 «Obligación de Juan Molina», fols. 51-51v. 
declara deber a Alonso Pascual la cantidad de 688 reales por 17 arrobas de bacalao de primera clase $\mathrm{c}^{79}$.

Las especias de azafrán, cacao, canela y azúcar fueron también abundantes entre las transacciones de la villa ${ }^{80}$, la mayoría entre comerciantes. Uno de estos productos para la exportación -el azafrán- y el resto en el caso de la importación. El suministro a las confiterías, pero también como un producto habitual en las tiendas, hacían del cacao, la canela y el azúcar -mayoritariamente traídos de Caracas a través de Valencia y Cádiz- un producto básico de comercio. Ya indicó Paloma Fernández, en su trabajo sobre los negocios mercantiles y las redes de parentesco en Cádiz, que el comercio colonial era un importante generador de fortunas ${ }^{81}$. Ejemplo de las múltiples compras de este bien es la transacción que queda reflejada en la obligación que firma Juan Zacarias Torres, comerciante albacetense. Éste dice deber la cantidad de 6.000 reales en 1818 por la compra de una partida de cacao y azúcar a Don Salvador Pérez, comerciante valenciano de la localidad de Monovar ${ }^{82}$. Estos comerciantes que compraban en Valencia y Cádiz distribuían estos productos a tenderos y a la población en general. Así, Pedro Juran, importante comerciante albacetense, vendió una porción de este bien a Simón García. Este último, maestro carpintero, dice deber al primero en 1781 la cantidad de 1.078 reales por: «89 libras de cacao de Caracas de buena calidad» ${ }^{83}$. También este producto solía importarse del puerto de Cartagena, aunque con menos asiduidad. Ejemplo de esto es la compra que hace el comerciante albacetense Pascual Pérez. Éste dice deber en 1817 a los Señores Fernández de la Compañía de Comercio de Cartagena, la cantidad de 38.446 reales por una partida de cacao, canela y azúcar ${ }^{84}$.

El azafrán seguía siendo pieza primordial del comercio de la villa. La mayoría de comerciantes importante albacetenses lo tenían como un bien básico de su mercadeo, y en algunos casos el principal de exportación. Antonio Santos Cuesta, por ejemplo, siguió firmando escrituras en los años 80' del Setecientos por la compra de este bien a labradores de Albacete o de otras localidades de alrededor. Después distribuía éste hacia Valencia, de donde traía las telas lujosas que después vendía en su tienda y lonja. Así, en el año de 1781, este comerciante protagoniza una de las escrituras de obligación. Éste dice deber a Juan Hernández, labrador, la cantidad de 26.852 reales por 223 libras y 8 onzas de azafrán tostado de buena calidad que éste le ha suministrado ${ }^{85}$.

79. AHPA Secc. Protocolos, leg. 1031 «Obligación de Juan Candelas», fols. 31-32.

80. En el caso de Gran Bretaña (PRICE, J.: «What did merchants do? Reflections on British overseas trade, 1660-1790», en Journal of Economic history, 49, 1989, pág. 269) hay que señalar la importancia que tuvo la reexportación de productos exóticos en el importante crecimiento del comercio en el siglo XVIII e incluso antes.

81. Fernandez Perez, P.: El rostro familiar de la metrópoli. Redes de parentesco y lazos mercantiles en Cádiz, 1700-1812, Madrid, Siglo XXI, 1997, pág. 13.

82. AHPA Secc. Protocolos, leg. 3318 «Obligación de Juan Zacarías Torres», fols. 330-331v.

83. AHPA Secc. Protocolos, leg. 3313 «Obligación de Simón García», fols. 14-14v.

84. AHPA Secc. Protocolos, leg. 1040 «Obligación de Pascual Pérez», fols. 81-81v.

85. AHPA Secc. Protocolos, leg. 3313 «Obligación de Antonio Santos Cuesta», fols. 41-41v. 
Para acabar con el tema de los alimentos y especias, hay que reseñar la importancia que siguió teniendo el vino en las transacciones, y también las bajocas, tanto verdes como blancas. Estas últimas eran suministradas desde Albacete a poblaciones cercanas como La Gineta por importantes comerciantes y también por tratantes al por menor. En el caso primero, Sebastián Rivera, vecino de La Gineta, dice deber en 1781 al comerciante José Beltrán 336 reales por 25 libras de bajocas ${ }^{86}$. En cuanto al vino, la importante producción de este bien hacía que abundara la compra en las Tercias Decimales de mosto para su elaboración, o bien para la fabricación de aguardiente. Pero también la compra de vino foráneo que estaba - en general- dado a monopolio a una persona. Algo que se comprueba en el caso de la obligación que realiza Martín Garrido, pequeño tratante, por la compra de vino tinto al regidor de Madrigueras Don José Paños por 600 reales en $1788^{87}$. Aunque lo habitual es la compra de mosto en las Tercias Decimales. En ellas participaban muchos comerciantes que, en varias ocasiones de manera conjunta, hacían una importante compra para después venderla en la población, o en otras localidades. Es el caso de la obligación que firman en conjunto Francisco Herráez Gascón, su sobrino Juan Herráez, y el primo de este último, Francisco Gómez. Éstos declaran deber al obispado de Cartagena en 1799 a través de las Tercias, la cantidad de 9.861 reales por la compra de 1.445 arrobas de vino de calidad y 142 arrobas de calidad inferior $^{88}$.

En cuanto al resto de bienes que aparecen en las obligaciones, sólo parece importante reseñar los bienes inmuebles y la tierra. Éstos aparecen con más asiduidad en las propias compra-ventas que se firman en protocolos. Son aproximadamente el $95 \%$ de estas escrituras. Pero también aparecen en las obligaciones cuando no se ha satisfecho el precio, cuando se aplaza el pago, o cuando se adeuda todavía una parte numeraria de la compra. En 1781 Francisco Ruescas, carretero, hace una compra de una casa a José Ruiz, por la que le deja a deber 1.333 reales $^{89}$. Ejemplo de la tierra es la compra de Juan Martínez Andújar. Éste compra a los comerciantes Don Pedro Crespo y Don José Baldos $^{90}$ - como fideicomisarios del también comerciante Don José Beltrán, fallecidoun viñedo por el precio de 2.400 reales $^{91}$.

La naturaleza de los deudores de escrituras de obligación en Albacete sigue un patrón muy común a anteriores periodos. Eso sí, incrementado su número por la gran cantidad de escrituras que se han tratado en esta época. En primer lugar aparecen personajes de los heredamientos y aldeas próximas a la villa para el abastecimiento.

86. AHPA Secc. Protocolos, leg. 3313 «Obligación de Sebastián Rivera», fols. 20-20v.

87. AHPA Secc. Protocolos, leg. 3316 «Obligación de Martín Garrido», fols. 163-163v.

88. AHPA Secc. Protocolos, leg. 1033 «Obligación de Francisco Herráez Gascón», fols. 115-115v.

89. AHPA Secc. Protocolos, leg. 3313 «Obligación de Francisco Ruescas», fols. 231-231v.

90. Como indica AGNEW, J.: Belfast merchant families...op. cit. pág. 47; la posesión de tierra confería status, y quienes la adquirían en importantes cantidades eran contados automáticamente entre la gentry, aunque como muy bien indica, sus «status exacto» era determinado por sus ancestros, y las afiliaciones familiares.

91. AHPA Secc. Protocolos, leg. 3316 «Obligación de Juan Martínez Andújar», fols. 145-145v. 
En segundo lugar hay que señalar la presencia cada vez más acusada del tránsito de personas de las localidades de la provincia, en busca de bienes y servicios difíciles de encontrar en las suyas ${ }^{92}$. Y finalmente algunos individuos de un radio más amplio (localidades murcianas, conquenses, alicantinas o valencianas), que adquirían en la población bienes que el constante transcurrir de arrieros y carreteros de vecinas localidades traían.

En primer lugar, los heradamientos ${ }^{93}$. Los principales productos que compraban eran dos: ganado y granos, especialmente trigo. En cuanto a lo primero, es bastante lógico. La necesidad de fuerza de tiro en las cada vez más extensivas tierras de cultivo, obligaban a acudir a la población albacetense en busca de este bien. Un bien que muy fácilmente podían adquirir en periodo de feria, donde llegaban cientos de mulas, asnos y bueyes. Así, Antonio Portero, labrador en el heredamiento de Molina, dice deber a Don Joaquín Peralta, tratante de ganado de Quintanar del Rey, 1.550 reales por la compra de una mula castellana ${ }^{94}$. Esta compra, realizada en el año de 1784, fue en la significativa fecha del 9 de septiembre, en plena feria de Albacete. En cuanto a los granos, gran parte de las compras las solían realizar a través de las Tercias Decimales. Muchos de los labradores de las heradamientos de Albacete -nos atreveríamos a decir que la mayoría- complementaban sus trabajos como labradores con el ejercicio de carreteros en diferentes momentos del año. El amplio número de galeras que en los heradamientos se reflejaron en los dos recuentos estadísticos de 1660 y de mediados del siglo XVIII así lo demuestra. De esta forma, en 1788 los labradores Gaspar Moreno y Francisco Miranda - del heredamiento de Casa Castillo- y José Miranda Menor -hijo del último y morador en el heredamiento de Malpelo- hacen una compra de granos en las Tercias Decimales. Los tres juntos afirman deber a la Iglesia Parroquial de Albacete la cantidad de 2.898 reales por: «15 fanegas de trigo y geja, 6 de cebada y dos y media de cebada de inferior calidad que han recibido» ${ }^{95}$.

Sobre el resto de poblaciones de la provincia, el ganado también sigue ocupando un papel primordial en las compra-ventas. Tobarra, Chinchilla, Peñas de San Pedro. La Gineta. Un largo número de tratantes y labradores de esas villas venían con asiduidad a la población albacetense en busca de ganado, sobre todo de tiro. En 1786, por ejemplo, Diego Cañete, vecino de Tobarra, declara deber a Don Agustín Peralta, tratante de ganado de Quintanar del Rey, la cantidad de 2.000 reales por una mula castellana ${ }^{96}$.

92. Hay que recordar el papel destacado de los centros urbanos como centros de consumo y de difusión de las nuevas pautas de consumo textil: BORSAY, P.: The English urban Renaissance. Culture and Society in the provincial town, 1660-1770, Oxford, 1989.

93. Tanto Jan De VRIES (La urbanización en Europa, 1500-1800... op. cit.); como Paul BAIROCH (Cities and economic development, Londres, 1988), ponen énfasis en la necesidad de estudiar las funciones comerciales y financieras de las zonas urbanas, y entre éstas, ver las estrechas relaciones con la zona circundante, en pos de apreciar las redes urbanas y comerciales de mejor modo.

94. AHPA Secc. Protocolos, leg. 3314 «Obligación de Antonio Portero», fols. 99-99v.

95. AHPA Secc. Protocolos, leg. 1031 «Obligación de Gaspar Moreno», fols. 97-97v.

96. AHPA Secc. Protocolos, leg. 3315 «Obligación de Diego Cañete», fols. 238-238v. 
También el caso de Benito Rodríguez en 1785, vecino de Chinchilla, que compra una mula cerril por 3.240 reales a Don Basilio Ochando, también tratante de ganado, pero esta vez de la población de Casas Ibáñez ${ }^{97}$.

El ganado es el principal producto de venta para las poblaciones de alrededor, pero también fueron otros productos los que se redistribuyeron a estas localidades. Así, en 1815 Pedro Córcoles, vecino de Peñas de San Pedro, decía deber al comerciante albacetense Antonio Tevar la cantidad importante de 64.000 reales $^{98}$. Ésta provenía de una compañía que hicieron ambos para el abastecimiento de carne de la villa de Peñas de San Pedro en 1810-1811, en el que Antonio Tevar le suministraba dicho bien de consumo. Esta cantidad, que no pudo satisfacer en vida, la tuvo que dejar adeudar a su viuda en su testamento. En 1822 Antonio Briz Vinuesa, comerciante albacetense, es protagonista en una escritura junto con un vecino de La Roda. José Antonio Alarcón, vecino de esa localidad manchega, se obligaba a pagar al comerciante de Albacete todos los años los géneros de cáñamo y bacalao que éste le suministra para su tienda. A cambio, el tendero rodense le daría a Antonio Briz la mitad de los beneficios que alcance con la venta de dichos géneros ${ }^{99}$.

También algunos bienes textiles se redistribuían a esas poblaciones cercanas. Ejemplo de esto es la escritura que en 1785 realizan conjuntamente los hermanos Francisco y Miguel Martinez Sanz, ambos vecinos de La Gineta. Éstos se obligan a pagar a Ana Gómez, viuda de Pablo Herráez, y María de Moya, viuda de Asensio Gómez, la cantidad de 1726 reales por 525 libras de cáñamo espadado de la mejor calidad $^{100}$. Se refleja pues esa posición de distribución de bienes de consumo que estaba adquiriendo la población albacetense en la comarca de La Mancha, como ya se ha comentado someramente a lo largo de este capítulo ${ }^{101}$.

Sobre el resto de poblaciones de donde proceden los deudores foráneos en estas escrituras, cabe hablar de cierta disparidad. Existen obligaciones, como la que firmaron Diego Serna y José Torres en 1789, que reflejan unas amplias redes comerciales. Así, Francisco Pla, un comerciante catalán vecino de Vie, se obligaba a pagar a dichos comerciantes albacetenses por toda la carne de cordero y las pieles que éstos le iban a suministrar en día de San Juan del año de $1790^{102}$. Quizás es importante el hecho de que Don Audal Sabater, como ya se ha indicado comerciante catalán afincado en Albacete

97. AHPA Secc. Protocolos, leg. 3314 «Obligación de Antonio Portero», fols. 115-115v.

98. AHPA Secc. Protocolos, leg. 1040 «Obligación de Pedro Córcoles», fols. 20-21v.

99. AHPA Secc. Protocolos, leg. 1041 «Obligación de José Antonio Alarcón», fols. 84-85.

100. AHPA Secc. Protocolos, leg. 1031 «Obligación de Migue Martínez Sanz», fols. 160-160v.

101. José Manuel BARTOlOMÉ BARTOLOMÉ («El consumo de textiles en León (1700-1860)», en Revista de Historia Moderna, 2003, n 21, pág. 488) también ha comprobado algo similar en el caso de La Bañeza y Astorga para su entorno rural. Éste indica como conclusiones parecidas pueden sacarse del estudio de para la Inglaterra del siglo XVIII: MCKANDRICK «The Consumer Revolution of Eighteenth-Century England», en The birth of a a consumer society. The commercialization of Eighteenth-Century England, Londres, 1982.

102. AHPA Secc. Protocolos, leg. 3316 «Obligación de Francisco Pla», fols. 59-60. 
y con una compañía de comercio, firmó como fiador de Francisco Pla. Este hecho reafirma lo que ya se ha venido comentando. Los comerciantes que vinieron de fuera -sobre todo catalanes y valencianos- para establecerse en la villa, visto la vitalidad comercial de la misma al final del siglo XVIII, ayudaron a que los tratantes y mercaderes de ésta se insertaran en redes comerciales más vastas e importantes ${ }^{103}$.

Por otro lado, y como en los anteriores periodos, los reconocimientos de deuda que tienen como acreedores a personajes foráneos ofrecen un radio de contactos mercantiles ampliamente diferente. Ahora, quizás, muy mediatizado por los tipos de transacciones que en ellas se dan. Así, por ejemplo, la gran presencia de Casas Ibáñez y sobre todo Quintanar del Rey se debe a la venta de ganado. En ellas los hermanos Don Joaquín y Don Agustín Peralta por parte de la villa de Quintanar suman una importante cifra ${ }^{104}$, mientras que por parte de Casas Ibáñez es Don Basilio Ochando el mayor beneficiado. Por otro lado, Cartagena está presente en un número tan amplio de escrituras por las Tercias Decimales, donde la mayoría de las ventas iban a parar a las arcas del obispado. Pero también están presentes muchas transacciones con compañías de comercio de esa localidad portuaria. Con Murcia ocurre algo muy parecido. Las deudas por distintas rentas, entre las que está implicado algún individuo de la élite murciana es causa de su importante presencia, a la que hay que sumar los contactos con comerciantes de la capital murciana. La presencia de Roma se debe al cardenal Celaya, cuyas rentas están presentes en las Tercias Decimales ${ }^{105}$. Este personaje, que vivió toda su vida en Roma, obtuvo este beneficio por parte de su padre, de origen murciano y compañero del Cardenal Belluga ${ }^{106}$. El caso de Madrid, Valencia y Alicante es completamente diferente, pues casi todas las escrituras en las que aparecen estas localidades, están protagonizadas por comerciantes y compañías de comercio de esas poblaciones. Refleja un tráfico comercial mucho más amplio y de mucha más importancia donde se fue consolidando la incipiente burguesía comercial albacetense.

Poco se puede decir más del tráfico del ganado en la población albacetense en relación con las poblaciones de Quintanar del Rey y Casas Ibáñez. Sólo comentar que

103. Según Jaume TORRAS («Redes comerciales y auge textil en la España del siglo XVIII», en BERG, M.: Mercados y manufacturas... op.cit. pág. 112) en la España del siglo XVIII era muy notorio la actividad de las «diásporas mercantiles»o redes comerciales integradas por mercaderes extranjeros o foráneos: «. Sobre el concepto de «diásporas comerciales» este autor hace referencia al trabajo: CURTIN, P. D.: Cross-cultural trade in World History, Cambridge, 1984, págs. 2-3.

104. Es curioso la gran cantidad de escrituras que entre ambos firman. La confianza de gran parte de los compradores en estos personajes, muy activos al menos durante la década de 1780, lleva a replantearse los mecanismos del mercado como simple oferta y demanda en esos momentos. Sin duda, la reputación, el crédito personal y las relaciones tienen un peso trascendental en las transacciones: MULDREW, C.: «Interpreting the market: the ethics of credit and community relation in early modern England», en Social History, 18, 1993, págs. 163-183.

105. Sobre las rentas eclesiásticas vid: REY CASTELAO, O.: «Las crisis de las rentas eclesiásticas en España: el ejemplo del Voto de Santiago», en Cuadernos de Investigación Histórica, n1 11, 1987, págs. 53-88

106. Sobre éste, vid: IRIGOYen LóPeZ, A.: Una Diócesis, un Obispo, un Clero: Luis Belluga, Prelado de Cartagena, Murcia, Real Academia Alfonso X El Sabio, 2005. 
todas las escrituras se refieren a compra-ventas de mulas. El ganado de tiro es el único que comercian los tratantes de estas localidades y en él, como ya se ha indicado, la mula le fue ganando terreno al buey. Es necesario reseñar cómo las transacciones de estos tratantes se realizaban con individuos de muchas localidades, mientras que con los de Albacete casi se limitaban a los heradamientos. Así, en 1782 Don Agustín Peralta vendía una mula a Juan López Godoy, vecino de Villarrobledo, de la que le quedó a deber a este último la suma de 820 reales $^{107}$. Curioso es el importante número de transacciones de ganado que se realizaron con la villa de Tobarra. El propio Don Agustín Peralta en el mismo año de 1782 realizaba otra transacción de una mula a Juan Noguera, vecino de Tobarra, de la que éste le quedaba a deber 1.000 reales $^{108}$. En el caso de Casas Ibáñez ya se ha comentado el peso las ventas de Don Basilio Ochando. En 1796 éste le vende un par de mulas a Juan Gómez, labrador y carretero de Albacete ${ }^{109}$. De dicha venta, el vecino albacetense le deja a deber 1.400 reales.

Muy diferente es el caso de Cartagena a través de las Tercias Decimales, donde lo principal es el trato de ganado caprino y lanar. Muchas veces son varios los labradores y tratantes que acudían a comprar estos bienes en conjunto. Es el caso de Roque Iniesta, de Barrax, Andres Fernández y Antonio López-Tello de Albacete en 1792. Éstos se obligan a pagar a la Fábrica Mayor de la Iglesia de Cartagena 1815 reales por la compra de 55 cabezas de ganado lanar y caprino ${ }^{110}$. También puede apreciarse lo mismo en ese año de 1792 entre Felipe García y Francisco Gómez Menor, comerciante ${ }^{111}$. Éstos dicen deber al Obispado de Cartagena la cantidad de 19.383 reales por 570 cabezas de ganado lanar y caprino ${ }^{112}$.

Por otro lado, los principales focos de contactos comerciales importantes en este momento son la propia Cartagena, Alicante, Valencia, algunas localidades catalanas ${ }^{113}$ y Madrid. Aunque aparece una sola vez Cádiz, se conoce por otras fuentes que el

107. AHPA Secc. Protocolos, leg. 3314 «Obligación de Juan López Godoy», fols. 113-113v.

108. AHPA Secc. Protocolos, leg. 3314 «Obligación de Antonio Portero», fols. 111-111v.

109. AHPA Secc. Protocolos, leg. 1033 «Obligación de Juan Gómez», fols. 63-63v.

110. AHPA Secc. Protocolos, leg. 1032 «Obligación de Antonio López-Tello», fols. 82-83.

111. Ya estudió Miguel Ángel MELÓN JiMÉNEZ («Algunas consideraciones en torno a la crisis de la transhumancia en Castilla», en Studia Historica, 1990, págs. 61-89) los mecanismos por los cuales los comerciantes de lana se fueron haciendo con hatos de ganado lanar cada vez mayores. Los dos procesos -adquisición de ganado lanar y comercio lanero- se haya íntimamente unidos:

112. «Obligación de Francisco Gómez Menor» AHPA Secc. Protocolos, leg. 1032, fols. 86-87v.

113. Ya se ha indicado la trascendencia que pudo suponer la presencia de comerciantes catalanes en muchas villas y ciudades castellanas y las redes mercantiles donde se insertaron. En el caso albacetense, estaba en el centro de la carretera que unía Barcelona con Madrid si se quería pasar por Valencia, una plaza comercial en alza en esos momentos. También el paso cada vez mayor de comerciantes catalanes hacia Andalucía al abrirse el monopolio americano propició esto. Sobre los contactos comerciales entre Cataluña y los puertos andaluces: NAVARRo MiralLES, L. J.: «Contactos comerciales entre el litoral catalán -costas, norte del corregimiento...» op. cit.; vid también en el caso murciano: PÉREZ PICAZO, M. T. y LEMEUNIER, G.: «Comercio y comerciantes catalanes en la crisis del Antiguo Régimen murciano», Primer Congrés d'Història Moderna de Catalunya, Barcelona, vol. 1, 1984 págs. 747-755. 
comercio con esta plaza mercantil fue importante en algunos mercaderes locales. Así en 1819 Pascual Pérez, comerciante albacetense, firma una escritura de obligación con un comerciante gaditano. En ella, el vecino de Albacete dice deber la cantidad de 20000 reales a Don Narciso Arbe por distintos géneros textiles y de especiería que le compró en su lonja gaditana.

Es con estas plazas comerciales cuando se aprecia nítidamente los contactos con compañías de comercio. Es curiosa la aparición de comerciantes franceses afincados en Valencia y con una compañía comercial en estas escrituras. Quizás la importante presencia de caldereros franceses en Albacete, como los maestros Revel y Juan Vázquez Vasión, ayudan a esto. Lo cierto, con todo, es que es abundante su aparición, ya desde la década de 1780. Así, el propio Pascual Pérez protagoniza una de ellas en 1782. Este comerciante dice deber a los señores José Pelussier y Antonio Galvien la cantidad de 593 pesos, 12 sueldos y 9 dineros -aproximadamente unos 2.500 reales- por distintos géneros textiles que el mercader albacetense ha adquirido ${ }^{114}$.

Ejemplo también de los contactos con compañías de comercio es la obligación que firma Antonio Santos Cuesta en 1786. Éste dice deber 5.106 reales a Don Antonio Ramos y su Compañía de Comercio de Alicante por distintos géneros textiles que el mercader alicantino le suministró ${ }^{115}$. Con respecto a Madrid, la escritura que firma Pedro Juran en 1784 es también un buen ejemplo. Este comerciante albacetense dice deber a Francisco Umaran y su Compañía de Comercio la cantidad de 13.477 reales por distintos géneros de ropa de lana y lienzos ${ }^{116}$.

En cuanto al comercio con otras plazas mercantiles de carácter internacional, creemos que éste tuvo que darse con relativa frecuencia por varios motivos. Uno de ellos es la importante presencia en los intercambios comerciales de mercaderes franceses afincados en Valencia. Este hecho, más el asentamiento de caldereros oriundos de Francia en la villa hace pensar unas relaciones bastante pronunciadas con el país vecino. Es más, hay multitud de escrituras que hacen referencia a la presencia de estos comerciantes franceses de forma continuada en la población albacetense. Así, Don Juan Ricord, comerciante francés residente en Valencia y que tenía una compañía de comercio, firma una escritura de poder en Albacete en $1795^{117}$. En la misma da el poder a su esposa e hijo para que sigan con sus negocios en Valencia, pues ha sido «extrañado» temporalmente del Reino de Valencia y ha decidido residir en Albacete. Los negocios mercantiles que fluían a través de la villa, y los cada vez más intensos contactos comerciales con Valencia en las dos últimas décadas del siglo XVIII, ayudan a comprender esta decisión. Sin duda, para el comerciante francés ésta fue la plaza mejor situada para poder seguir vigilando sus negocios en la no tan alejada ciudad, y seguir con otros desde otro lugar, también de muy vital importancia mercantil. Además, éste

114. AHPA Secc. Protocolos, leg. 1030 «Obligación de Pascual Pérez», fols. 191.

115. AHPA Secc. Protocolos, leg. 3315 «Obligación de Antonio Santos Cuesta», fols. 35-36.

116. AHPA Secc. Protocolos, leg. 1030 «Obligación de Pedro Juran», fols. 151-152v.

117. AHPA Secc. Protocolos, leg. 1036 «Poder de Juan Ricord», 27/07/1795. 
no vino solo. Don José Pelussier, bastante conocido por los comerciantes albacetenses, da un poder a su esposa y a cu cuñado ${ }^{118}$-hijo del anterior comerciante reseñado- para que lleven sus negocios en Valencia mientras éste reside en Albacete por los mismos $\operatorname{motivos}^{119}$. De igual cariz es el poder que otorga el mismo día el también comerciante francés Don Claudio Bodoy Lavat ${ }^{120}$. Lo cierto es que la presencia de estos hombres de grandes negocios mercantiles se hace sentir en todos los ámbitos de la vida social albacetense, igual que lo hizo en un caso bastante parecido como la ciudad de Santander ${ }^{121}$ en el ámbito costero o Caravaca de la $\mathrm{Cruz}^{122}$ en un enclave interior.

De los negocios con el extranjero algo sabemos por la escritura de emancipación que hizo Don Ignacio Suárez, comerciante albacetense, a su hijo como requisito previo para acceder a la regiduría perpetua en la villa. Tras declarar los bienes que disponía en su tienda -seda, paños, lienzos, especias y múltiples vales de compra- dice dejar a su hijo los contactos que disponía en las plazas comerciales con las que él tenía encuentros mercantiles. Éstas eran Cádiz (por el comercio de especias como cacao, azúcar o canela provenientes de Caracas), Alicante, Murcia y Valencia (en el que trataba con seda e intercambiaba un bien tan preciado como el azafrán), y Bilbao, Vizcaya y el extranjero (en el que comerciaba con lana y traía paños elaborados franceses y de la zona de los Países Bajos, pues éste era también uno de sus productos de mercadeo) ${ }^{123}$.

Sin embargo, escasas son las escrituras que se han encontrado en el que uno de los implicados sea comerciante residente en el extranjero. Se pueden resaltar dos, que son sumamente significativas. En una de ellas Gines Lario Mayor que, como ya se indicó en el impuesto sobre tiendas y criados, poseía una tienda de Listonería, polvora y plomos. Éste declara deber 2.400 reales a Don Juan Domingo Prodeider, comerciante alemán que residía temporalmente en Valencia. Esta deuda, firmada en 1792, era por

118. AHPA Secc. Protocolos, leg. 1036 «Poder de Don José Pelussier», 27/07/1795.

119. Son interesantes, a este respecto, las sugerencias de Sara PENNELL («Consumption and consumerism in Early Modern England», en The Historical Journal, vol. 42, nº 2, 1999, pág. 563) acerca de los estudios sobre el consumo. En ellas dice cómo hay también que adentrarse en la organización doméstica, en los estándares de vida y la construcción de experiencias de la vida material. La reconstrucción de experiencias de vida, como la de este comerciante francés, y otros, puede ayudar a conocer las pautas de consumo en una localidad como Albacete a través de las redes en las que pudo introducir éste a otros mercaderes albacetenses.

120. «Poder de Don Claudio Bodoy Lavat» AHPA Secc. Protocolos, leg. 1036, 27/07/1795.

121. MARURI VillanUeVA, R.: «Vestir el cuerpo, vestir la casa. El consumo...» op. cit. pág. 161.

122. En el trabajo: Pellegrin Abellán, J. A.: Las élites de poder en Caravaca en la segunda mitad delsiglo XVIII. Patrimonio, poder politico y actitudes ante la muerte, Tesis Doctoral inédita, Murcia, Universidad de Murcia, 1999; se aprecia perfectamente el papel de comerciantes extranjeros y su relevancia social; también vid: PÉREZ PICAZO, M ${ }^{\mathrm{a}}$ T.: «El comercio murciano de la Segunda Mitad del siglo XVIII», en La economía de la Ilustración, Cuadernos del Seminario Floridablanca, $\mathrm{n}^{\circ}$ 2, Murcia, Universidad de Murcia, 1988; PÉrez PICAZO, M ${ }^{\mathrm{a}}$ T.: Caravaca de la Cruz 1755, Madrid, Colección Alcabala del Viento, 1993.

123. AHPA, Secc. Protocolos, leg. 1032 «Escritura de cesión de Don Ignacio Suárez», 22/12/1790. 
una partida de «géneros de su comercio» ${ }^{124}$, por lo que suponemos que estaría relacionado con el hierro o la metalurgia. También existe una escritura que declara una deuda procedente del comercio con un mercader de París. En ella Felipe Risueño, comerciante albacetense, junto con su yerno Antonio Molas Bordo, comerciante y vecino de Murcia, declaran deber 14.000 reales a Don Luis Jorge Champenois por distintos género de comercio en $1801^{125}$.

\section{CONCLUSIÓN}

Con todo lo descrito en este trabajo puede afirmarse que los años finales del Antiguo Régimen fueron de especial trascendencia para la villa de Albacete. Y no sólo a nivel económico, sino también a nivel político y social. En este periodo se experimentaron algunas transformaciones económicas en la villa que se vieron reflejadas en su estructura social y en las redes clientelares ${ }^{126}$. Se produjo una lenta, pero continua, renovación de las oligarquías locales, al mismo tiempo que se iba transformando la orientación económica de la población. En una localidad de un carácter agrario bastante importante, los grandes propietarios siguieron teniendo un fuerte peso en las decisiones políticas y en la estructura socio-económica. Éste es un hecho indudable. Pero también lo es que la formación de un grupo social -heterogéneo, sí- pero de gran fuerza, irrumpió en las redes clientelares y de poder. El poderío económico ya no sólo dependía de las fanegas de tierra que se poseían, los hatos de ganado lanar, la cantidad de viñedos, azafrán y otros terrenos. Los contactos mercantiles, el peso del tráfico financiero y las redes de comercio de lujosos productos traídos de lejos, pusieron a un nuevo grupo social en la órbita del poder.

Crecimiento comercial, incremento demográfico, desarrollo urbano y formación y consolidación de un grupo burgués mercantil fue paralelo, complementario y recíproco $^{127}$. La transición hacia el sistema capitalista ponía sus bases en Albacete desde el comercio y los movimientos financieros, muy ligados ambos a la producción agraria. Al igual que en el caso de la seda murciana en el siglo XVII donde los comerciantes de esta ciudad tuvieron una situación propicia para desarrollarse como grupo social -como burguesía comercial ${ }^{128}$ - los mercaderes albacetenses hicieron lo propio con el

124. AHPA Secc. Protocolos, leg. 1032 «Obligación de Gines Lario Mayor», fol. 1-1v.

125. AHPA Secc. Protocolos, leg. 1036 «Obligación Felipe Risueño», 03/11/1801.

126. En el caso de Santander, Ramón MARURI VILLANUEVA («Vestir el cuerpo, vestir la casa. El consumo...» op. cit. pág. 173) dice que las transformaciones que se contemplaban en esa ciudad en 1830 desde 1750 eran importantes. Entre los factores que impulsaron la población estaba el crecimiento demográfico, el proceso de urbanización, los cambios en la estructura socio-ocupacional, muy vinculados al crecimiento numérico de la propia burguesía mercantil:

127. Ya apuntó WRIGLEY (Historia y población. Introducción a la demografía histórica, Barcelona, Crítica, 1994pág. 108) sobre lo intrincado de las relaciones entre demografía y estructura social y económica de la población, tanto en su funcionamiento, como en los procesos de cambio.

128. Miralles Martinez, P.: La sociedad de la seda: comercio, manufactura y relaciones sociales en Murcia durante el siglo XVII, Murcia, Universidad de Murcia, 2002. 
azafrán, el comercio de granos y-minoritariamente- la lana. La situación geográfica de la villa ponía a esta población en el centro de muy distintos flujos comerciales, de muy diferente densidad, fuerza y dirección, pero que siempre pasaban por ella. Una fuerza centrífuga arrastró los negocios mercantiles desde las poblaciones cercanas a la villa de Albacete como centro distribuidor y redistribuidor. Esa fuerza se acentuó a partir de 1780 gracias al establecimiento de la Feria Franca en la población, así como por las oleadas de capital mercantil que -debido al contacto con comerciantes internacionales afincados en Valencia y Madrid- inundaban la villa. Esto fortaleció a esa burguesía comercial.

Muchos de los datos de los que se disponen pueden corroborar el crecimiento de los grupos burgueses ligados al comercio a finales del Antiguo Régimen, sobre todo en las poblaciones donde éste se dio de forma propicia. Como se ha comentado, Miguel Ángel Melón Jiménez lo ha atestiguado para Cáceres, donde se produjo un importante crecimiento del capital comercial y financiero ${ }^{129}$. Alberto Angulo también lo ha corroborado para los comerciantes vitorianos ${ }^{130}$. Lo mismo cabe decir de los comerciantes leoneses de La Bañeza ${ }^{131}$ o del Bierzo ${ }^{132}$, la burguesía santanderina ${ }^{133}$, los comerciantes valencianos que ha estudiado Ricardo Fanch $^{134}$ o los mercaderes de la capital madrileña ${ }^{135}$. Estos actores sociales participaron en la modificación que se llevó a cabo en las estructuras sociales y económicas a finales del Antiguo Régimen. Pero ni todas ellas fueron de igual calado, ni de la misma naturaleza. En el caso extremeño, Miguel Ángel Melón afirma que las actividades de estos comerciantes agilizaron algunas aletargadas formas económicas, así como pondría las bases de un capitalismo agrario que apostó por la agricultura como sector productivo frente a otros como la manufactura ${ }^{136}$. Algo parecido ocurrió en Murcia en el Setecientos con los comerciantes de seda ${ }^{137}$, y lo

129. Los orígenes del capital comercial y financiero... op. cit.

130. Del éxito en los negocios al fracaso... op. cit.

131. Rubio PÉRez, L. M.: La burguesía maragata. Dimensión social, comercio y capital en la Corona de Castilla durante la Edad Moderna, León, Universidad de León, 1995.

132. BARTOLOMÉ BARTOLOMÉ, J. M.: La hegemonía de una nueva burguesía en el Bierzo (1800-1850). Las transformaciones económicas y sociales durante la crisis del Antiguo Régimen, León, 2000.

133. MARURI VillanUEVA, R.: La burguesia mercantil santanderina, 1700-1850 (cambio social y dementalidad), Santander, 1990.

134. Franch BenAVENT, R.: Crecimiento comercial y enriquecimiento burgués en la Valencia del siglo XVIII, Valencia, Institucio Valenciana D'estudis i investigacio, 1986.

135. Sola CorbaChO, J. C.: «El papel de la organización familiar en la dinámica del sector mercantil madrileño a finales del siglo XVIII», en Historia Social, 1998, n 32, págs. 3-21; CRUZ, J.: Los notables de Madrid. Las bases sociales de la Revolución Liberal Española, Madrid, Alianza Editorial, 2000.

136. Sobre este tema: GARCÍA SANZ, A.: «Desarrollo del capitalismo agrario en Castilla y León en el siglo XIX. Algunos testimonios, algunas reflexiones y un epílogo», en YUN CASALILLA, B. (Coord.): Estudios sobre capitalismo agrario... op. cit.

137. Miralles MartíneZ, P.: Seda, trabajo y sociedad en la Murcia del siglo XVII, Murcia, 2000, pág. 876. 
mismo en Albacete con el azafrán y el comercio de granos ${ }^{138}$. Pero ¿el enriquecimiento de las familias ligadas al comercio aseguraría el desarrollo industrial, un nuevo orden social y la eclosión final del sistema del Antiguo Régimen? Evidentemente la respuesta es compleja.

No hay que olvidar que detrás de este proceso está la cuestión de la revolución burguesa y de la propia burguesía ${ }^{139}$. Y es que este grupo, en tanto clase social revolucionaria y emergente, no termina de encajar en nuestra historia social, política y económica $^{140}$. Si según muchos autores la economía española fracasó, sobre todo a nivel agrario, esto impidió una verdadera revolución industrial ${ }^{141}$. Además, esta cuestión propició el pacto entre este grupo social y la nobleza, lo que acarrearía también -como consecuencia- un fracaso en la revolución de carácter burgués ${ }^{142}$. El problema reside en la asociación que se ha realizado con asiduidad entre el crecimiento comercial y económico, la formación de este grupo social y la revolución burguesa e industrial en sí. Y es que la mayor problemática para abordar estas cuestiones es la aureola con la que ha impregnado la teoría de la modernización a la burguesía ${ }^{143}$. Esta teoría, de un marcado carácter finalista, impondría sobre el grupo burgués el papel revolucionario que traería el progreso, el capitalismo y la modernización. Por lo cual, si hay burguesía, debe haber revolución burguesa, y si esto no se produce hay que buscar soluciones

138. Estamos, entonces, de acuerdo con la opinión que HoBSBAWM, E.: La Era de la Revolución, 1789-1848, Barcelona, Editorial Crítica, 1997, pág. 20; dice en su obra sobre la era de las revoluciones. Según este autor, en el periodo entre 1780 y 1790, las ciudades de tipo provinciano (como podemos considerar la villa de Albacete a finales del siglo XVIII) tiene como clase mediana a los traficantes de cereales y ganado, los transformadores de los productos agrícolas, los abogados y los notarios, así como los mercaderes que adquirían y revendían los productos de mujeres manufactureras.

139. RomAnELli (Borghesia, büegertum, bourgeosie. Itinarari europei di un consetto», en KocKA, J.: Borghesie europee dell'Ottocento, Venecia, 1989, pág. 70) ya señaló que el carácter relacional y no objetivo del concepto de burguesía implica su varabilidad de usos y también la dificultad de definición.

140. CRUZ, J.: Los notables de Madrid... op. cit. pág. 13.

141. NADAL J.: El fracaso de la Revolución Industrial en España, 1814-1913, Barcelona, Ariel, 1975.

142. Todo ello emana según Jesús CRUZ (Los notables de Madrid... op. cit. pág. 13) de los trabajos presentados para el homenaje a Artola, publicados en tres volúmenes: VVAA: Antiguo Régimen y Liberalismo. Homenaje a Miguel Artola, 3 vols, Madrid, Alianza, 1994-1995.

143. Así es por ejemplo como Alberto MARCOS MARTín «Historia y desarrollo: el mito historiográfico de la burguesía», en ENCISO RECIO, L. M.: La burguesía española en la Edad Moderna, Valladolid, Universidad de Valladolid, 1996.) cree que se ha impuesto un mito historiográfico de la burguesía que se ha creado a partir de la premisa de que este grupo social es el principal artífice del cambio social, político y económico que se vivió desde 1750 a 1850 por una supuesta incompatibilidad con el sistema del Antiguo Régimen. 
alternativas como el fracaso de este grupo o la ya famosa traición de la burguesía ${ }^{144}$ que señaló Fernand Braudel ${ }^{145}$.

El impulso económico del siglo XVIII favoreció la acumulación de capital en los estratos superiores del campesinado, que fue ganando enteros con la comercialización y especulación de granos ${ }^{146}$. Pervivió un capital mercantil que se beneficiaba todavía de las esferas especulativas y de pura intermediación, lo que frenaba-según Bartolomé Yun- el desarrollo protoindustrial que fuera capaz de inducir cambios más profundos de la economía ${ }^{147}$. De esta manera, como ocurrió en Albacete o Cáceres, se incidió en la agricultura como forma productiva donde se iniciaron mayores inversiones. Lo que creó - por cierto- unos importantes contrastes entre la presencia de capital financiero y las formas productivas agrarias que llevaría al capitalismo agrario del siglo XIX. No hay que olvidar que entre los grandes beneficiarios del crecimiento del Setecientos estaban los importantes terratenientes, los recolectores de tributos o arrendatarios de los mismos. El hecho de que gran parte de las familias burguesas participaran de este beneficio, dificulta que se rebelaran contra esta forma de apropiación del producto.

Hay que pensar que esa especialización económica y comercial de muchas regiones españolas pudo suponer tanto un incentivo para el crecimiento de signo moderno, como un freno ${ }^{148}$. Mientras que la especialización que vivió la región catalana en la industria $^{149}$ y el comercio de larga distancia puso las bases de su desarrollo industrial en el siglo XIX, la opción agraria de las regiones de la Castilla interior reforzó el papel periférico que tuvieron en la economía española a partir de la centuria del Ochocientos. Todo ello pese al crecimiento comercial que muchas villas y ciudades del interior vivieron en el siglo XVIII. Como indica Jaume Torras, la economía española adquirió en esta centuria algunos rasgos nuevos que fueron decisivos para la indus-

144. Cuestión debatida en relación a la crisis de la aristocracia por Yun CASALILLA, B.: «¿Traición de la burguesía Vs. Crisis de la aristocracia? Por una revisión de la historia social y de la cultura de la Europa del Antiguo Régimen», en SAnZ AyÁN, C. y GARCÍA GARCíA, B. J.: Banca, crédito y capital. La Monarquía Hispánica y los antiguos Países Bajos (1505-1700), Madrid, Fundación Carlos Amberes, 2006, págs. 512-531.

145. BRAUDEL, F.: El Mediterráneo y el mundo mediterráneo en la Época de Felipe II, Madrid, 1976.

146. Yun CASAlilla, B.: La transición al capitalismo en Castilla ... op. cit. pág. 599.

147. La teoría de la protoindustrialización la desarrollaron en un principio JONES («Agricutural origins of industry», en Past and Present, 40, 1968); Franklin MENDELS («Proto-industrialization: the first phase of the industrialization process», en Journal of Economic History, 32, 1972); y MEDICK, SCHLUMBOHM y KRIEDTE (Industrialización antes de la industrialización, Barcelona, Crítica, 1986).

148. MoRENO FERNÁNDEZ, J. R.: «La articulación y desarticulación de regiones económicas...» op. cit. pág. 247.

149. La innovación en la industria lanera, pero sobre todo en la algodonera, así como la fabricación de papel, pusieron a la región catalana como una de las mejores preparadas para acometer la industrialización del siglo XIX, gracias a los carriles de la innovación: BENAULT, J. M y y SÁNCHEZ, A.: «El legado industrial del Antiguo Régimen», en El legado económico del Antiguo Régimen, Barcelona, Editorial Crítica, 2004, págs. $187-228$. 
trialización, un proceso que fue muy concentrado territorialmente ${ }^{150}$. Se concentró en aquellas regiones que se especializaron en un comercio no supeditado a la producción agraria, como ocurrió en gran parte del interior castellano.

Esto lleva, pues, a plantearse la capacidad del capital comercial para la transformación del viejo orden socio-económico feudal ${ }^{151}$. Hasta qué punto ese capital transformó la sociedad y la economía es una pregunta muy difícil de responder. Que produjo un cierto cambio en las estructuras socio-económicas es un hecho probado allí donde el capital comercial actuó con relativa importancia. En Albacete, el desarrollo del comercio fue una de las principales causas del crecimiento demográfico, urbano y de la formación y consolidación de un grupo social concreto. Pero ¿esto desarticuló el sistema de relaciones sociales y de producción existente? Quizás más que desarticularlo, lo que consiguió fue reformarlo en beneficio de un grupo social en alza que se estaba beneficiando de ese desarrollo mercantil.

Siguiendo a Bartolomé Yun Casalilla, la crisis del Antiguo Régimen no fue tanto por intencionalidad de una mejora de futuro como de una pugna por el control del poder y del reparto del producto social y económico ${ }^{152}$. Pero en nuestra opinión esto no se dio entre distintos grupo sociales (burguesía-nobleza), sino entre facciones, grupos y clientelas, entre los que -ahora sí- se encontraban unas familias que se enriquecieron gracias a ese capital comercial y a la expansión e integración del mercado.

150. TORRAS, J.: «Redes comerciales y auge textil...» op. cit. pág. 132.

151. MARcos Martín, A.: España en los siglos XVI, XVII y XVIII. Economía y sociedad, Barcelona, Crítica, 2000, pág. 695.

152. La transición al capitalismo en Castilla ... op. cit. pág. 602. 